\title{
Geological and isotopic characteristics of granites from the Western Pernambuco-Alagoas Domain: implications for the crustal evolution of the Neoproterozoic Borborema Province
}

\author{
Caracterização geológica e isotópica dos granitos do Domínio \\ Pernambuco-Alagoas Oeste: implicações na evolução crustal da \\ Província Borborema
}

\author{
Rodrigo Fabiano da Cruz ${ }^{1 *}$, Márcio Martins Pimentel², Ana Cláudia de Aguiar Accioly ${ }^{1}$, \\ Joseneusa Brilhante Rodrigues ${ }^{1}$
}

\begin{abstract}
The Western Pernambuco-Alagoas Domain is a complex tectonic domain of the Southern part of the Neoproterozoic Borborema Province. It borders the Northern margin of São Francisco Craton. $\mathrm{U}-\mathrm{Pb}$ and $\mathrm{Sm}-\mathrm{Nd}$ data discussed in this work show that, in the Western Pernambuco-Alagoas Domain, large volumes of granitic rocks of various ages related to different tectonic events are recognized. The Cariris Velhos Event is represented by Lobo $(974 \pm 8 \mathrm{Ma}$ ) and Rocinha (956 $\pm 2 \mathrm{Ma})$ orthogneisses; whereas Paleoproterozoic and Archean basement rocks are represented by Fulgêncio Orthogneiss (1,996 \pm 8 Ma), Riacho Seco Gneissic-migmatitic Complex $(1,992 \pm 27 \mathrm{Ma})$, and orthogneisses of Entremontes Complex $(2,734 \pm 11 \mathrm{Ma})$. Six groups of granitoids are recognized: Brasiliano granitoids (Ediacaran-Cryogenian), with Mesoto Paleoproterozoic model ages; Cariris Velhos granitoids (Tonian) yielding Mesoproterozoic model ages; Paleoproterozoic granitoids from Pernambuco-Alagoas Domain, with Neoarchean to Paleoproterozoic Nd model ages; Paleoproterozoic granitoids from Riacho Seco Nucleus, represented by Riacho Seco Gneissic-migmatitic Complex, with Archean model ages; Archean granitoids represented by the rocks of Entremontes Complex; and granitoids emplaced in the São Francisco Craton displaying Paleoproterozoic to Archean model ages. Prominent among the new data obtained is the Paleoproterozoic age of Riacho Seco Gneissic-migmatitic Complex, which is formed by Archean basement reworking. The new data reveal the presence of Paleoproterozoic and Archean basement inliers and a large volume of Cariris Velhos granitoids in the Western Pernambuco-Alagoas Domain. The orogen, therefore, involved extensive reworking of older blocks, possibly including parts of São Francisco-Congo Craton.
\end{abstract}

KEYWORDS: Neoproterozoic Orogen; U-Pb Geochronology; Sm-Nd Isotopes; Entremontes Complex; Riacho Seco Nucleus; Fulgêncio Orthogneiss.
RESUMO: O Dominio Pernambuco-Alagoas ao Oeste é um complexo dominio tectônico na parte Sul da Provincia Borborema Neoproterozoica. Faz fronteira com a margem Norte do Cráton de São Francisco. Dados U-Pb e Sm-Nd deste trabalho mostram que, no Dominio Pernambuco-Alagoas Oeste, grandes volumes de rochas graniticas de várias idades, relacionados a diferentes eventos tectônicos, são reconhecidos. O Evento Cariris Velhos é representado pelos ortognaisses Lobo $(974 \pm 8 \mathrm{Ma})$ e Rocinha (956 $\pm 2 \mathrm{Ma}$ ); enquanto que o Ortognaisse Fulgêncio (1.996 $8 \mathrm{Ma}$ ), o Complexo Gnáissico-migmatítico Riacho Seco $(1.992 \pm 27 \mathrm{Ma})$ e ortognaisse do Complexo Entremontes (2.734 $\pm 11 \mathrm{Ma}$ ) representam o embasamento Paleoproterozoico e Arqueano. Seis grupos de granitoides são reconhecidos: Brasilianos (Ediacarano-Criogeniano), com idades modelo do Meso ao Paleoproterozoico; Cariris Velhos (Toniano), apresentando idades modelo mesoproterozoicas; paleoproterozoicos do Dominio Pernambuco-Alagoas, com idades modelo do Neoarqueano ao Paleoproterozoico; paleoproterozoicos do Núcleo Riacho Seco, representado por complexo gnáissico-migmatítico homônimo, com idades modelo arqueanas; arqueanos representadas pelas rochas do Complexo Entremontes; e granitoides do Cráton Säo Francisco, exibindo idades modelo do Arqueano ao Paleoproterozoico. Destacam-se entre os novos dados obtidos a idade paleoproterozoica do Complexo Gnáissicomigmatítico de Riacho Seco, formado pela retrabalhamento de rochas arqueanas. Os novos dados revelaram a presença de inliers de embasamento Arqueano e Paleoproterozoico e um grande volume de granitoides Cariris Velhos no Dominio Pernambuco-Alagoas Oeste. Portanto, o orógeno envolveu retrabalhamento de blocos mais antigos, possivelmente incluindo partes do Cráton São Francisco-Congo.

PALAVRAS-CHAVE: Orógeno Neoproterozoico; Geocronologia U-Pb; Isótopos de Sm-Nd; Complexo Entremontes; Núcleo Riacho Seco; Ortognaisse Fulgêncio.

1Serviço Geológico do Brasil - SGB/CPRM, Brasília (DF),Brazil.E-mails: rodrigo.cruz@cprm.gov.br; ana.accioly@cprm.gov.br; joseneusa.rodrigues@cprm.gov.br ${ }^{2}$ Laboratório de Geocronologia, Universidade de Brasília - UnB, Brasília (DF), Brazil. E-mail: marcio@unb.br

*Corresponding author

Manuscrito ID: 30073. Recebido em: 28/12/2013. Aprovado em: 07/10/2014. 


\section{INTRODUCTION}

The Borborema Province (Almeida et al. 1977), in Northeastern Brazil, underlies an area of approximately $450,000 \mathrm{~km}^{2}$, corresponding to the Western portion of the extensive Brasiliano-Pan African orogenic system formed by a convergence of the West Africa/São Luis and San Francisco-Congo Cratons (Fig. 1). The study area is located in the Pernambuco-Alagoas Domain (PEAL) and its subdomain, the Riacho Seco Nucleus (RSN) in the Southern Borborema Province. The PEAL is located between the E-W Pernambuco Lineament to the North and the Sergipano Belt, and São Francisco Craton to the South. This is one of the crustal blocks comprising the Southern Subprovince of Van Schmus et al. (2011) or the Southern Domain of Brito Neves et al. (2000), which are part of the Neoproterozoic orogenic system along the Northern margin of São Francisco Craton.

The subdomain RSN was previously considered a small Archean block within the younger PEAL. The correlation between PEAL with other domains of the Borborema Province is still unclear, as well as the ages of their main units and tectonic events recorded in its rocks. In this study, we present $\mathrm{U}-\mathrm{Pb}$ zircon ages, $\mathrm{Nd}$ isotopes, and geological and geochemical data of metagranites from the PEAL. Five rock units were studied and dated by U-Pb zircon dating, using Laser Ablation Inductively Coupled Plasma Mass Spectrometry (LA-ICP-MS): Entremontes Complex, Fulgêncio orthogneiss, Riacho Seco Gneissic-migmatitic Complex, Lobo and Rocinha orthogneisses. The types of analysis that each geologic unit were subjected are summarized in Tab. 1. Some isotope analyzes of the granitoids from Sáo Francisco Craton were performed to compare with the bodies studied in the PEAL. The new data clarified several aspects of the geology of the western segment of PEAL and its role in the tectonic evolution of the Borborema Province along the Northern margin of São Francisco Craton.

\section{ANALYTICAL PROCEDURES}

Several outcrops were described and samples were collected, some of them were selected for petrographic, geochemical, and isotopic studies (Tab. 1). The most representative bodies to understand the geological setting were subjected to more detailed studies. The methodology of this study is explained as follows: - The petrographic analysis helped defining the composition and metamorphic grade of the main units.

- Major and trace element contents were determined to establish the main group of granitoids (Entremontes Complex, Fulgêncio and Rocinha orthogneisses). Data obtained in this study were added to the geochemical ones of Salgueiro and Parnamirim Brazil Geological Service (CPRM) maps. All samples were prepared (by fusion with lithium metaborate and aqua regia digestion), and their major and trace element analyses performed by SGS Laboratories Geosol Ltda., using ICPMS technology.

- The isotopic study was the main goal of the investigation, with analyses of whole rock $(\mathrm{Sm}-\mathrm{Nd})$ and zircon grains (U-Pb). Zircon concentrates were separated from approximately five-kilogram samples. The concentration of heavy minerals was carried out by panning, which was followed by magnetic separation and final selection under a binocular microscope. Zircon grains were arranged in mounts made of epoxy resin that were polished to expose inside the grains. They were imaged using a scanning electron microscope (SEM) equipped with cathode luminescence (CL) and backscattered electron (BSE) detectors in order to select the best spots for mineral analyses. The U-Pb evaluations were carried out with a Thermo-Finnigan multi-collector LA-ICP-MS installed at the Geochronology Laboratory of University of Brasília (samples RF-111, RF-243 and RF-270) and at the Laboratory of Isotope Geology of the Federal University of Rio Grande do Sul (samples RF-179 and RF-323). Ages were calculated using the ISOPLOT 3.0 software (Ludwig 2000). Twenty to 40 spot analyses were carried out for each sample. The Sm-Nd isotopic analyses were performed at both mentioned university laboratories and both followed the method described by Gioia and Pimentel (2000). In this procedure, approximately $50 \mathrm{mg}$ of the sample is mixed with a powdered tracer solution $\left({ }^{149} \mathrm{Sm}\right.$ and $\left.{ }^{150} \mathrm{Nd}\right)$, then dissolved by repeated acid attacks. Sm and $\mathrm{Nd}$ are extracted using cationic exchange columns. Purified aliquots of $\mathrm{Sm}$ and $\mathrm{Nd}$ are deposited on Re filaments. Isotopic analyses were carried out by Thermal Ionization Mass Spectrometry (TIM). Instrument fractionation on ${ }^{143} \mathrm{Nd} /{ }^{144} \mathrm{Nd}$ ratios was corrected applying the ${ }^{146} \mathrm{Nd} /{ }^{144} \mathrm{Nd}$ ratio of 0.7219 . The $\mathrm{T}_{\mathrm{DM}}$ values were calculated using De Paolo's model (1981).

\section{BORBOREMA PROVINCE}

Borborema Province (Almeida 1967; Almeida et al. 1977) consists of a mosaic of tectonic blocks including varied proportions of Paleoproterozoic basement and scattered Archean nuclei, Meso- to Neoproterozoic supracrustal rocks, and large intrusions of granitic rocks emplaced during the Neoproterozoic Brasiliano orogen, in 650 to $580 \mathrm{Ma}$ (Van Schmus et al. 2008; Brito Neves et al. 2000). The Neoproterozoic evolution of the Borborema Province took place during the West Gondwana agglutination 


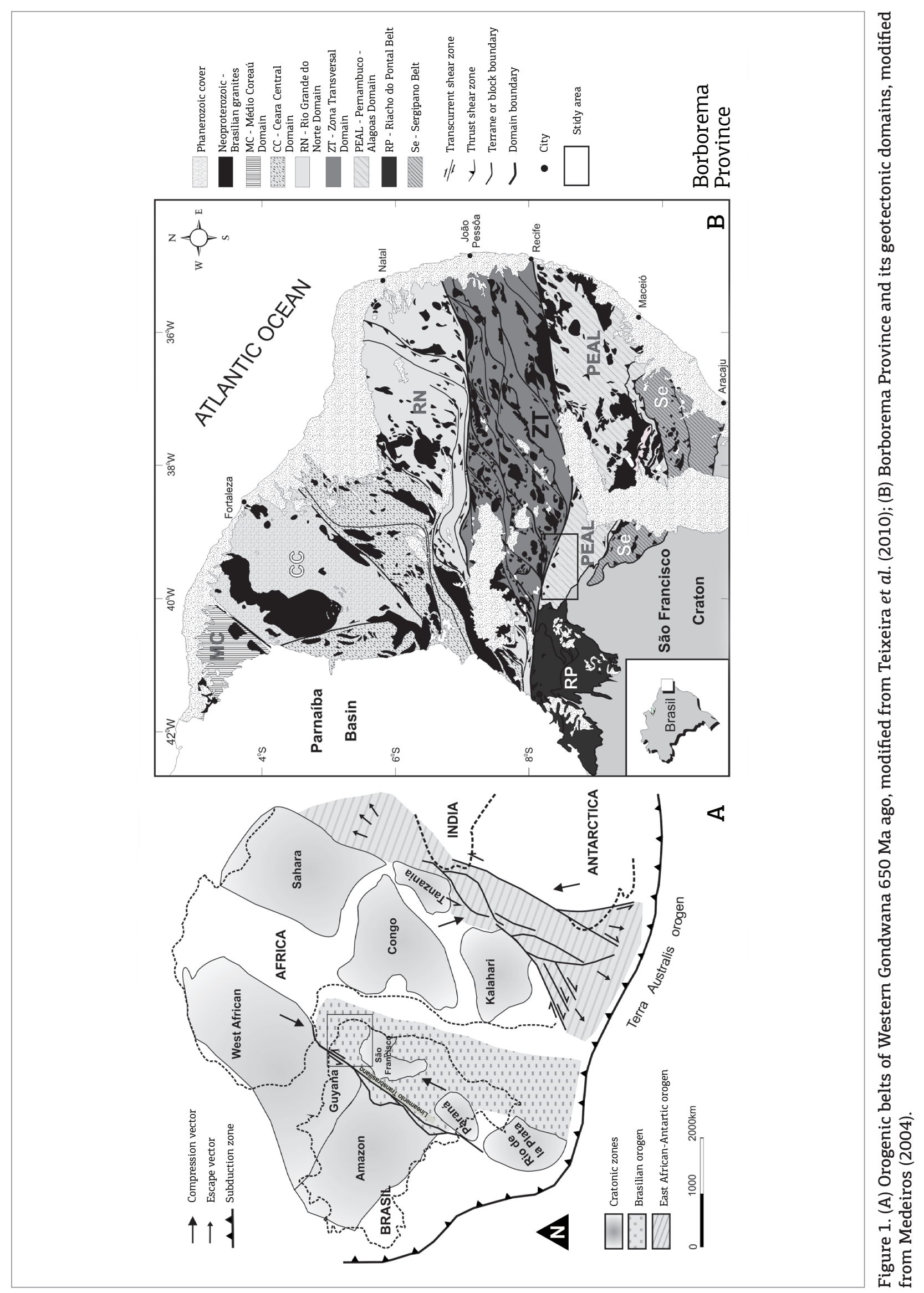


Table 1. Summary of samples collected.

\begin{tabular}{|c|c|c|c|c|c|c|}
\hline Unit & Point & Coord_X & Coord_Y & Chemistry & Sm-Nd & $\mathrm{U}-\mathrm{Pb}$ \\
\hline \multicolumn{7}{|l|}{ Brasiliano granites } \\
\hline Ibó Migmatite & RF022 & 471224 & 9045282 & & $\mathrm{x}$ & \\
\hline Ibó Migmatite & RF068 & 463255 & 9029986 & & $\mathrm{x}$ & \\
\hline Chorrochó Augen-gneiss & RF027 & 471119 & 9033550 & & $\mathrm{x}$ & \\
\hline \multirow[t]{2}{*}{ Bendó Orthogneiss } & RF415 & 443316 & 9082776 & & $\mathrm{x}$ & \\
\hline & RF322 & 438801 & 9069760 & & $\mathrm{x}$ & \\
\hline \multicolumn{7}{|l|}{ Cariris Velhos granites } \\
\hline Lobo Orthogneiss & RF270 & 472784 & 9069820 & & $\mathrm{x}$ & $\mathrm{x}$ \\
\hline Rocinha Orthogneiss & RF010 & 488055 & 9048504 & & $\mathrm{x}$ & \\
\hline Rocinha Orthogneiss & RF033 & 466796 & 9041103 & $\mathrm{x}$ & $\mathrm{x}$ & \\
\hline Rocinha Orthogneiss & RF311 & 432497 & 9072305 & $\mathrm{x}$ & & \\
\hline Rocinha Orthogneiss & RF323 & 439101 & 9068004 & $\mathrm{x}$ & $\mathrm{x}$ & $\mathrm{x}$ \\
\hline Rocinha Orthogneiss & RF323B & 438698 & 9068243 & $\mathrm{x}$ & & \\
\hline Rocinha Orthogneiss & RF323C & 439368 & 9067372 & $\mathrm{x}$ & & \\
\hline Rocinha Orthogneiss & RF466 & 439784 & 9067173 & $\mathrm{x}$ & & \\
\hline Rocinha Orthogneiss & RF467 & 440177 & 9066216 & $\mathrm{x}$ & & \\
\hline Rocinha Orthogneiss & FL180 & 447512 & 9077182 & $\mathrm{x}$ & & \\
\hline Rocinha Orthogneiss & FL181 & 446766 & 9077557 & $\mathrm{x}$ & & \\
\hline Rocinha Orthogneiss & SF182 & 447364 & 9075216 & $\mathrm{x}$ & & \\
\hline \multirow[t]{2}{*}{ Rocinha Orthogneiss } & FL185 & 446365 & 9073209 & $\mathrm{x}$ & & \\
\hline & RF003 & 472752 & 9056286 & & $\mathrm{x}$ & \\
\hline \multicolumn{7}{|l|}{ Paleoproterozoic granites } \\
\hline Fulgêncio Orthogneiss & RF040 & 450613 & 9045530 & $\mathrm{x}$ & $\mathrm{x}$ & \\
\hline Fulgêncio Orthogneiss & RF240 & 417807 & 9050234 & $\mathrm{x}$ & & \\
\hline Fulgêncio Orthogneiss & RF241 & 416630 & 9052437 & $\mathrm{x}$ & & \\
\hline Fulgêncio Orthogneiss & $\mathrm{RF} 242$ & 415278 & 9052878 & $\mathrm{x}$ & & \\
\hline Fulgêncio Orthogneiss & RF243 & 415448 & 9055151 & $\mathrm{x}$ & $\mathrm{x}$ & $\mathrm{x}$ \\
\hline Fulgêncio Orthogneiss & RF244 & 413205 & 9057996 & $\mathrm{x}$ & $\mathrm{x}$ & \\
\hline Fulgêncio Orthogneiss & RF267 & 415503 & 9068278 & $\mathrm{x}$ & $\mathrm{x}$ & \\
\hline Fulgêncio Orthogneiss & RF287 & 413833 & 9067886 & $\mathrm{x}$ & & \\
\hline Fulgêncio Orthogneiss & RF288 & 415434 & 9067893 & $\mathrm{x}$ & & \\
\hline Fulgêncio Orthogneiss & RF289 & 416240 & 9067910 & $\mathrm{x}$ & & \\
\hline Fulgêncio Orthogneiss & RF292 & 452458 & 9065471 & $\mathrm{x}$ & & \\
\hline Fulgêncio Orthogneiss & RF328 & 415508 & 9069694 & $\mathrm{x}$ & & \\
\hline Fulgêncio Orthogneiss & RF579 & 411536 & 9060713 & $\mathrm{x}$ & & \\
\hline RSGMC* & RF111 & 434681 & 9037013 & & $\mathrm{x}$ & $\mathrm{x}$ \\
\hline RSGMC $^{*}$ & RF136 & 426457 & 9031204 & & $\mathrm{x}$ & \\
\hline Caraíbas Migmatite & RF128 & 430882 & 9042347 & & $\mathrm{x}$ & \\
\hline Caraíbas Migmatite & RF249 & 424686 & 9044946 & & $\mathrm{x}$ & \\
\hline SFCG** & RF171 & 422407 & 9029967 & & $\mathrm{x}$ & \\
\hline \multirow[t]{2}{*}{$\mathrm{SFCG}^{* *}$} & RF261 & 400890 & 9026667 & & $\mathrm{x}$ & \\
\hline & RF165 & 447126 & 9051506 & & $\mathrm{x}$ & \\
\hline \multicolumn{7}{|l|}{ Archean granites } \\
\hline Entremontes Complex & RF179 & 400755 & 9090278 & $\mathrm{x}$ & $\mathrm{x}$ & $\mathrm{x}$ \\
\hline Entremontes Complex & RF262 & 396905 & 9072702 & $\mathrm{x}$ & & \\
\hline Entremontes Complex & RF403 & 391342 & 9084593 & $\mathrm{x}$ & & \\
\hline Entremontes Complex & RF425 & 400081 & 9089589 & $\mathrm{x}$ & & \\
\hline Entremontes Complex & RF454 & 418990 & 9088526 & $\mathrm{x}$ & & \\
\hline Entremontes Complex & RF503 & 391666 & 9089173 & $\mathrm{x}$ & & \\
\hline
\end{tabular}


(Trompette 1994). In paleogeographic reconstructions, the province extends from Central and Northeastern Brazil to West Africa through the Neoproterozoic orogenic areas of Cameroon, Nigeria, Niger, Algeria, Togo, and Benin (Fig. 1). This Province includes a complex system of high-temperature crustal scale shear zones that separate the province into tectonic domains, and they also control the emplacement of granites during the Brasiliano/Pan-African orogeny (Caby et al. 1991; Jardim de Sá 1994; Vauchez et al. 1995).

The province has been studied for decades, and different authors developed evolution models and configuration of their different domains (Almeida et al. 1981; Brito Neves 1983; Brito Neves et al. 1982, 2000; Jardim de Sá 1994; Sial 1986; Neves 2003; Silva Filho et al. 2002; Santos et al. 2010; Van Schmus et al. 1995, 2011; Ganade de Araújo et al. 2014. In this paper, the internal divisions of the Borborema Province used are based on models put forward by Van Schmus et al. (1995, 2008), Brito Neves et al. (2000) and Santos et al. (2000, 2010). They subdivided the province into three sub-provinces (Fig 1):

- Northern, including Médio Coreaú, Ceará Central and Rio Grande do Norte domains;

- Central (or Transversal Zone) with Piancó-Alto Brígida, Alto Pajeú, Alto Moxotó and Rio Capibaribe domains or terranes, and

- Southern or External, including Riacho do Pontal, Pernambuco-Alagoas and Sergipano domains.

The Northern Sub-province is exposed to the North of Patos Shear Zone, and consists mainly of Paleoproterozoic basement (including some Archean nuclei) partially covered by Neoproterozoic supracrustal rocks and intruded by Brasiliano plutonic rocks. The Central Sub-province is exposed between Patos and Pernambuco shear zones, and it is mainly characterized by the NE-SW to EW transcurrent faults system. The Southern Sub-province, confined between Pernambuco Shear Zone and São Francisco Craton, includes Sergipano and Riacho do Pontal supracrustal belts and Pernambuco-Alagoas Domain, which can be divided into Western and Eastern segments, separated by Tucano-Jatobá Cretaceous sedimentary basin (Angelim \& Kosin 2001), as seen in Fig. 1.

\section{Main tectonic domains and events}

\section{Archean and Paleoproterozoic rock units}

Archean rock units are not widespread in Borborema Province and they form small inliers or nuclei among Paleoproterozoic terrains, such as São José do Campestre Massif comprising rocks with U-Pb zircon ages between 3.4 and 2.7 Ga (Dantas et al. 1998; 2004); Troia-Pedra Branca Block, where orthogneisses of Cruzeta Complex gave U-Pb zircon ages between 2.85 and 2.64 Ga (Fetter 2000); and Entremontes Complex with orthogneiss dated by U-Pb zircon data as $2.734 \pm 11 \mathrm{Ga}$ (Cruz 2013). Paleoproterozoic basement in the Borborema Province includes rocks formed during three major events, with ages at 2.35, 2.15 and 2.0 Ga (Dantas 1997; Neves et al. 2006; Souza et al. 2007). On the African counterpart (Congo Craton), Lerouge et al. (2006) have reported SHRIMP U-Pb zircon ages of 2,066 and 2,044 Ma for the emplacement of granitoids and of ca. 2050 and $1985 \mathrm{Ma}$ for metamorphic events. These ages from African and South-American counterparts represent a segment of the Eburnean-Trans-Amazonian orogeny that resulted in the formation of a possible Paleoproterozoic supercontinent.

\section{Cariris Velhos Event}

Additionally to the Paleoproterozoic tectonic events, rocks that form Borborema Province were also affected by Cariris Velhos (1.0 - $0.9 \mathrm{Ga})$ and Brasiliano events $(650$ - $580 \mathrm{Ma})$. The Cariris Velhos Belt consists of augen gneisses, metasedimentary and metavolcanic rocks (felsic and mafic). Kozuch (2003), Brito and Cruz (2009), Santos et al. (2010) and Van Schmus et al. (2010) have constrained Cariris Velhos Event between 990 and $940 \mathrm{Ma}$, based on SHRIMP U-Pb in detrital zircon grains from metasedimentary rocks, as well as on TIMS and LA-ICPMS U-Pb data of orthogneiss and volcanic rocks.

The Cariris Velhos Event (Santos 1995) was originally defined as an orogenic event forming an extensive metamorphic belt, inserted within Alto Pajeú Domain (Brito Neves et al. 1995; Santos et al. 2010). Other authors (Bittar 1998; Neves 2003) argue, however, that Cariris Velhos Event represents an extensional event associated with continental rifting, which formed rocks dated between 1.0 and $0.9 \mathrm{Ga}$. This latter interpretation was based on the geochemical nature of volcanic and plutonic rocks, as well as on the absence of metamorphic zircon ages in the range between 1.0 and $0.9 \mathrm{Ga}$.

\section{Brasiliano Orogeny}

The Brasiliano Orogeny $(650$ - $500 \mathrm{Ma})$ affected the whole Borborema Province and was responsible for the regional deformation and medium- to high-grade metamorphism, for the generation and emplacement of large volumes of granite throughout the province, and also for the development of continental-scale transcurrent shear zones, which is one of the main characteristics of the province. Two main models have been used to describe the geodynamic evolution of Borborema Province during the Neoproterozoic. In one of them, the Borborema Province is considered the product of an accretionary event involving the collage of several allochthonous terrains (Brito Neves et al. 2000; Santos et al. 2004). The other 
model suggests an intra-plate setting in which reworking of pre-existing Archean-Paleoproterozoic crust and deposition of Proterozoic volcano-sedimentary sequences took place in an intra-continental environment (Neves 2003; Neves et al. 2014; 2006). A new model proposed by Ganade de Araújo et al. (2014), based on some aspects of the mentioned ones, suggests that the Borborema Province underwent two major collisional events, one between 620 and $610 \mathrm{Ma}$ and another between 590 and 580 Ma.

\section{Brasiliano magmatism}

The Brasiliano magmatism is symbolized by a series of granitoids with different types and dimensions. Most of the Neoproterozoic granite genesis is coeval with the development of large shear zones, which exerted strong tectonic control on the emplacement of the granitoids (Caby et al. 1991; Vauchez et al. 1995). The older Neoproterozoic plutons $(640-610 \mathrm{Ma})$ are more strongly deformed, suggesting the pre- to syn-tectonic nature of intrusions. Younger plutons $(590-570 \mathrm{Ma})$, on the other hand, are mostly undeformed and are therefore considered to be late- to post-tectonic intrusions. All schemes of classification of the Neoproterozoic granitic magmatism in NE Brazil (e.g. Almeida et al. 1977; Sial 1986; Guimarães et al. 1998) describe the increasing alkalinity of the magmatism with time, starting with normal calc-alkaline rocks and ending with alkali-rich granites and shoshonites. The most recent classification is from Van Schmus et al. (2011), who recognized five stages: Phase I, consisting of pre-collisional granitoids $(650-610 \mathrm{Ma})$; Phase II, syn-collisional granites (610 - $595 \mathrm{Ma})$; Phase III, post-collisional, pre-transcurrent granites $(595-576 \mathrm{Ma})$; Phase IV, syn-transcurrent intrusions (576-560 Ma); and Phase V, post-tectonic granites $(550-530 \mathrm{Ma})$.

\section{Western Pernambuco-Alagoas Domain}

The PEAL is an East-West oriented tectono-stratigraphic block of the Southern part of Borborema Province (Van Schmus et al. 2008). It was originally defined as a massif formed by Archean to Paleoproterozoic gneisses and migmatites, intruded by Brasiliano granitic bodies (Brito Neves et al. 1982). PEAL (Fig. 2) is now considered a complex tectonic domain including units of various ages (Van Schmus et al. 1995; Silva Filho et al. 2002; Oliveira et al. 2006; Cruz 2013; Cruz et al. In press). Two main units in the Western segment of the domain are recognized (Santos 1995; Medeiros \& Santos 1998; Medeiros 2000): Cabrobó Complex comprising metavolcanosedimentary and metasedimentary sequences metamorphosed under amphibolite facies conditions, with local migmatites, and Belém do São Francisco Complex formed mainly by granitic-granodioritic gneisses and migmatites with remnants of supracrustal rocks and mafic lenses. U-Pb dating on zircon of granodiorite gneiss of Belém do São Francisco Complex indicated the age of 2,074 $\pm 34 \mathrm{Ma}$ (Silva et al. 2002).

The metamorphic complexes of PEAL are intruded by variably deformed pre- to post-tectonic Neoproterozoic plutonic rocks. Recent U-Pb zircon data produced during mapping projects of the Brazilian Geological Survey, as well as by the present work suggest that Belém do São Francisco Complex may be divided into different units: Neoarchean Entremontes Complex, Orosirian Fulgêncio Orthogneiss, and Lobo and Rocinha orthogneisses related to Tonian Cariris Velhos Event. Besides the wide range of ages found in PEAL rocks, the structural complexity of the area is also noteworthy with thrust sheets in contact with São Francisco Craton and Sergipano and Riacho do Pontal belts. Transcurrent zones along the contact with the Transversal Zone to the North are recognized.

The RSN (Santos 1995; Angelim \& Kosin 2001) has been considered the exposure of older (Archean) rock units enclosed within PEAL. It may be subdivided into two major units (Cruz et al. In press): Riacho Seco Gneissic-migmatitic Complex that is made up of gneissic rocks, generally migmatized, including remnants of medium- to high-grade supracrustal rocks, and Riacho Seco Metasedimentary Complex represented by schists and gneisses of medium to high metamorphic grade, calcium-silicates rocks, and marbles. A Rb-Sr isochron on migmatites indicates an age of $2.9 \mathrm{Ga}$ for these rocks (Mascarenhas \& Garcia 1989), whereas a Sm-Nd $\left(\mathrm{T}_{\mathrm{DM}}\right)$ model age for Riacho Seco orthogneisses is ca. 3.1 Ga (Angelim \& Kosin 2001). Both ages suggest an overall Archean age for the RSN rocks. Such nucleus is partially surrounded by the Cabrobó Complex along a contractional shear zone. In the South, it is in contact with São Francisco Craton through the sinistral transcurrent Riacho Seco Shear Zone.

\section{Archean granitoids}

\section{Entremontes Complex}

The Entremontes Complex (Cruz 2013) consists mainly of granitic and minor granodioritic gneisses, as well as of some local amphibolite outcrops. The petrographic analyses of the granitic gneiss show that the main mafic mineral is amphibole (hornblende and hastingsite), followed by biotite, and minor garnet and clinopyroxene (hedenbergite). Migmatism and compositional banding are common, as well as milonitic structures as mineral stretching. The metamorphic conditions reached the medium grade (recrystallization of K-feldspar+biotite+amphibolite), with retrogression to lower grade (biotite recrystallized). The geochemical analyzes resulted in high $\mathrm{SiO}_{2}$ contents (74 to 70\%), as 


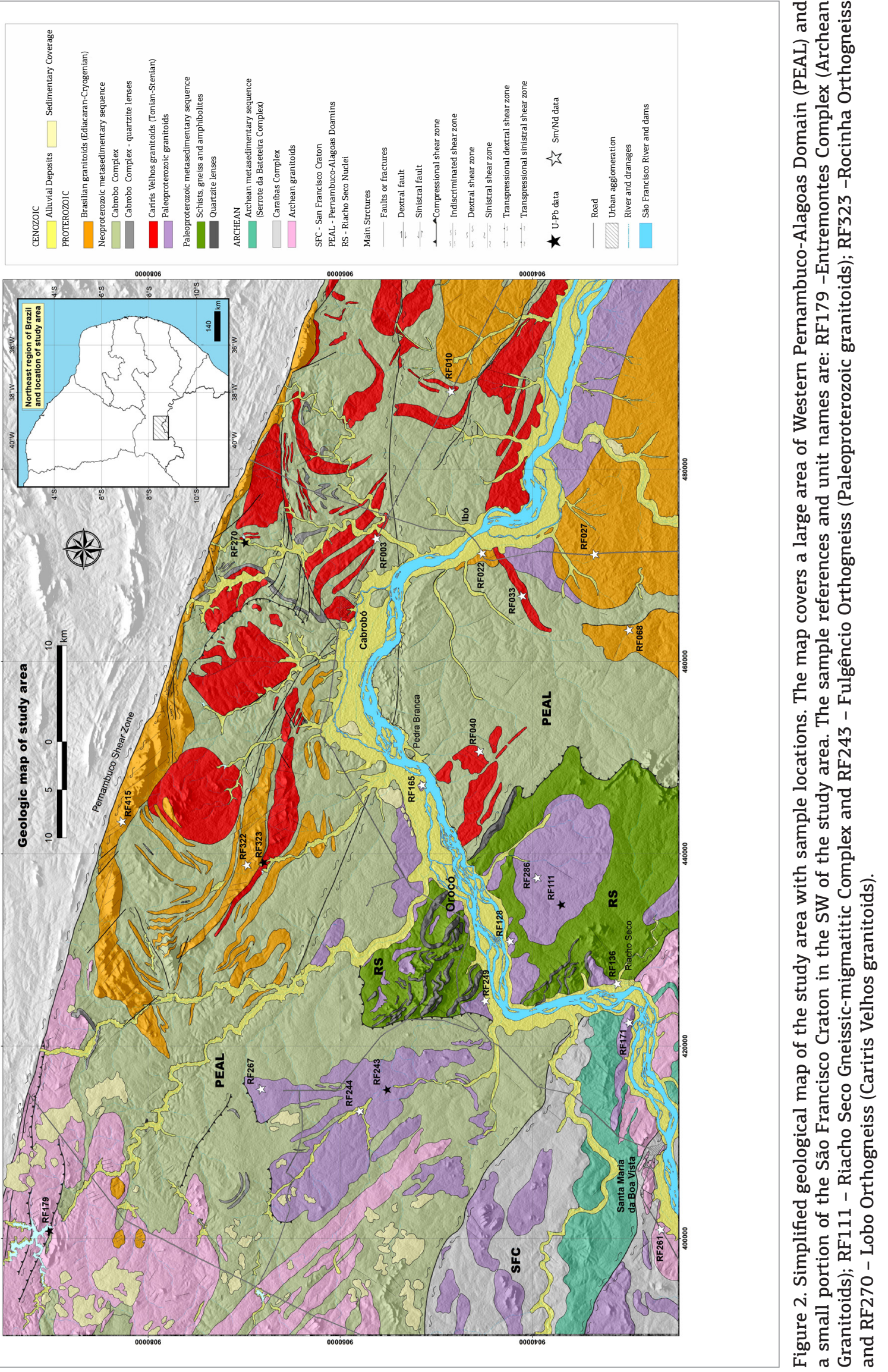


seen in Tab. 2, and metaluminous to peraluminous high-K calc-alkaline to alkaline compositions (Figs. 3A to 3C). In chondrite-normalized REE diagram (Boynton 1984), the patterns show fractionation between HREE and LREE and negative Eu anomalies (Fig. 4A). The primordial mantle normalized spidergram (Wood et al. 1979) presents negative anomalies of $\mathrm{Ba}, \mathrm{Nb}, \mathrm{Ta}, \mathrm{U}$, and $\mathrm{Sr}$ as well as strong negative Ti anomaly and marked enrichment in Tb and Y (Fig. 4D), some of these characteristics are also viewed in the ORG normalized spidergram (Pearce 1984), as seen in Fig. 4G. In Pearce's (1994) diagram (Fig. 5A), samples fall in the post-collisional to intra-plate field and according to the criteria (A1/A2) established by Eby (1992), they fall in the WPG+ORG and A2 field, indicative of A-type granites derived from mixed sources (Figs. 5B to 5D). The Entremontes Complex, as indicated by chemical data, is related to A-type magmatism most likely in a post-collisional setting.

\section{Paleoproterozoic granitoids}

Paleoproterozoic granites of PEAL in the studied area include granitic migmatites and orthogneisses found in the vicinities of Orocó, Pernambuco State (Orocó Migmatites), and Fulgêncio Orthogneisses; those from RSN comprising granitic migmatite exposed along São Francisco River near Orocó city, Pernambuco state (Caraíbas migmatites), and Riacho Seco Gneissicmigmatitic Complex; and São Francisco Craton granitoids including a pink alkaline migmatite near Riacho Seco and a biotite gneiss with sillimanite and garnet found near Santa Maria da Boa Vista, Pernambuco.

\section{Fulgêncio Orthogneiss}

This is a porphyroblastic coarse-grained migmatitic orthogneiss that contains discontinuous bands of concentrations of feldspar augen. In outcrops located to the South, the augen texture predominates, and structures like banding are scarce. Other structural features are shear bands with predominant dextral sense, mineral stretching lineation oriented North to South and low-to medium-angle foliation dipping to the West. Biotite is the main mafic mineral, accessory minerals are apatite, titanite, zircon, allanite, and opaque minerals. The recrystallization of K-feldspar and presence of metamorphic amphibole indicate upper greenschist to amphibolite facies, with retrogression to greenschist facies indicated by biotite recrystallization. An additional petrographic facies of these orthogneisses is found at the NW portion of the exposure area, consisting of fine-grained banded rocks. Inter-fingering of the two textural facies was found in some outcrops.
The geochemical analyzes show $\mathrm{SiO}_{2}$ contents ranging between 65 and 74\% (Tab. 3) and present high-K calcalkaline and metaluminous to peraluminous nature (Figs. 3A to 3C). The REE diagram (Boyton 1984), as seen in Fig. 4B, shows strong fractionation between LREE and HREE and negative Eu anomalies. In the primordial mantle-normalized spidergram (Wood et al. 1979), as in Fig. 4E, negative anomalies of $\mathrm{Ba}, \mathrm{Nb}, \mathrm{U}, \mathrm{Ti}$ and $\mathrm{Y}$ are observed, some of them are also seen in the ORG normalized spidergram (Pearce et al. 1984), Fig. 4H, suggesting the presence of subduction-related metasomatized mantle in their genesis. Very low concentrations of $\mathrm{Sr}$ indicate a marked fractionation of plagioclase in the original magma. In the tectonic discrimination diagram of Pearce et al. (1994), Fig. 5A, these samples correspond to post-collisional granitic composition, close to the boundary between syn-collisional and volcanic arc granite fields. In Eby (1992) diagrams, the samples demonstrate characteristics of late- to post-collisional tectonic setting with a probably mixed magma source (Figs. 5B to 5D).

\section{Riacho Seco Gneissic-migmatitic Complex}

This complex consists of orthogneisses with remnants of supracrustal rocks. It comprises the basement rocks of RSN, in this subdomain the supracrustal sequence is represented by Riacho Seco Metasedimentary Complex. The main rock types identified are reddish granitic orthogneiss with biotite and subordinately granodioritic orthogneiss with titanite and hornblende. They show subtle to well-developed compositional banding by different proportions of mafic minerals. Some outcrops are migmatitic locally mafic gneisses and amphibolite lenses are also present. Mineral textures (K-feldspar porphyroblasts) and paragenesis (recrystallized K-feldspar+biotite+amphibole) seen in the felsic gneisses suggest an amphibolite-facies metamorphism. The garnet-diopside-amphibole paragenesis, locally recognized, suggests that the unit might have reached the granulite facies with subsequent retrogression to amphibolite/upper greenschist facies.

\section{Cariris Velhos granitoids}

The Cariris Velhos granites (Tonian-Stenian) are represented by a migmatized granite body near to Cabrobó city in Pernambuco state (Cabrobó migmatite), and also by Lobo and Rocinha orthogneisses.

\section{Lobo Orthogneiss}

Lobo Orthogneiss defined by Brito and Freitas (2011) comprises medium- to fine-grained 
Table 2. Geochemical data from Entremontes Complex.

\begin{tabular}{|c|c|c|c|c|c|c|}
\hline \multicolumn{7}{|c|}{ Entremontes Complex } \\
\hline SAMPLE & RF-425 & RF-179 & RF-503 & RF-454 & RF-262 & RF-403 \\
\hline \multicolumn{7}{|l|}{ Wt \% } \\
\hline $\mathrm{SiO}_{2}$ & 72.55 & 71.55 & 71.78 & 73.66 & 73.41 & 71.49 \\
\hline $\mathrm{TiO}_{2}$ & 0.26 & 0.3 & 0.41 & 0.34 & 0.38 & 0.49 \\
\hline $\mathrm{Al}_{2} \mathrm{O}_{3}$ & 11.43 & 11.82 & 11.75 & 11.37 & 11.77 & 11.91 \\
\hline $\mathrm{Fe}_{2} \mathrm{O}_{3}$ & 3.25 & 3.85 & 4.9 & 4.25 & 4 & 4.58 \\
\hline $\mathrm{CaO}$ & 0.9 & 1.2 & 1.3 & 1 & 0.98 & 1.55 \\
\hline $\mathrm{Cr}_{2} \mathrm{O}_{3}$ & $<0.01$ & $<0.01$ & $<0.01$ & $<0.01$ & $<0.01$ & $<0.01$ \\
\hline $\mathrm{K}_{2} \mathrm{O}$ & 6.35 & 6.13 & 4.3 & 4.9 & 5.31 & 5.3 \\
\hline $\mathrm{MgO}$ & 0.09 & 0.26 & 0.13 & 0.26 & 0.12 & 0.39 \\
\hline $\mathrm{MnO}$ & 0.05 & 0.05 & 0.08 & 0.08 & 0.07 & 0.08 \\
\hline $\mathrm{Na}_{2} \mathrm{O}$ & 2.44 & 2.69 & 2.96 & 2.76 & 2.69 & 0.33 \\
\hline $\mathrm{P}_{2} \mathrm{O}_{5}$ & 0.06 & 0.1 & 0.03 & 0.04 & $<0.01$ & 0.06 \\
\hline Sum & $<0.01$ & $<0.01$ & 0.08 & 0.1 & 0.06 & 0.04 \\
\hline LOI & 97.38 & 97.89 & 97.71 & 98.75 & 98.79 & 96.21 \\
\hline \multicolumn{7}{|l|}{$\mathrm{ppm}$} \\
\hline $\mathrm{Ba}$ & 613 & 742 & 994 & 1026 & 884 & 883 \\
\hline $\mathrm{Be}$ & 3.2 & 3.4 & 4 & 0.4 & 3.2 & 0.4 \\
\hline Cs & 0.18 & 0.06 & 0.22 & 0.34 & $<0.05$ & 0.18 \\
\hline $\mathrm{Ga}$ & 21.4 & 19.4 & 23.5 & 22.1 & 26.6 & 21.9 \\
\hline $\mathrm{Hf}$ & 13.69 & 13.36 & 16.01 & 17.72 & 17 & 13.79 \\
\hline $\mathrm{Nb}$ & 28.7 & 25.03 & 24.29 & 19.46 & 30.04 & 31.07 \\
\hline $\mathrm{Rb}$ & 162 & 144 & 137 & 164 & 160 & 162 \\
\hline Sn & 8.4 & 6.3 & 4.9 & 6.3 & 4.1 & 3.9 \\
\hline $\mathrm{Sr}$ & 52.9 & 77.6 & 95.6 & 70.3 & 62.5 & 77 \\
\hline $\mathrm{Ta}$ & 2.09 & 2.87 & 1.34 & 1.39 & 1.02 & 1.65 \\
\hline Th & 33.9 & 20.5 & 15.3 & 19 & 27.3 & 15.1 \\
\hline $\mathrm{U}$ & 1.58 & 1.95 & 1.62 & 1.94 & 1.69 & 1.64 \\
\hline $\mathrm{W}$ & 2.2 & 0.2 & 0.9 & 1.2 & $<0.1$ & $<0.1$ \\
\hline $\mathrm{Y}$ & 71.17 & 67.82 & 63.14 & 84.57 & 84.23 & 69.74 \\
\hline $\mathrm{Zr}$ & 521 & 597 & 657 & 629 & 547 & 554 \\
\hline $\mathrm{Ag}$ & 0.02 & 0.03 & 0.08 & 0.11 & 0.1 & $<0.01$ \\
\hline $\mathrm{Au}$ & $<0.1$ & $<0.1$ & $<0.1$ & $<0.1$ & $<0.1$ & $<0.1$ \\
\hline As & $<1$ & $<1$ & $<1$ & $<1$ & $<1$ & 2 \\
\hline $\mathrm{Bi}$ & $<0.02$ & $<0.02$ & $<0.02$ & $<0.02$ & $<0.02$ & $<0.02$ \\
\hline $\mathrm{Cd}$ & 0.06 & 0.02 & 0.11 & 0.09 & 0.09 & 0.04 \\
\hline Co & 1 & 1.4 & 1.7 & 2.7 & 1.7 & 3.6 \\
\hline $\mathrm{Cu}$ & 3.8 & 3.1 & 9.1 & 11.3 & 3.9 & 15.4 \\
\hline $\mathrm{Hg}$ & $<0.01$ & $<0.01$ & $<0.01$ & 0.05 & 0.01 & 0.02 \\
\hline Mo & 0.45 & 1.9 & 2.86 & 1.34 & 2.09 & 2.95 \\
\hline $\mathrm{Ni}$ & 1.9 & 1.2 & 6 & 2 & 1 & 3.7 \\
\hline $\mathrm{Pb}$ & 2.6 & 1.8 & 2.2 & 5.4 & 3.7 & 3.4 \\
\hline $\mathrm{Sb}$ & $<0.05$ & $<0.05$ & $<0.05$ & $<0.05$ & $<0.05$ & $<0.05$ \\
\hline Se & $<1$ & $<1$ & 2 & 3 & $<1$ & 2 \\
\hline $\mathrm{Zn}$ & 41 & 31 & 53 & 67 & 70 & 43 \\
\hline $\mathrm{Ce}$ & 224.7 & 170.4 & 194.9 & 224.3 & 222.5 & 199.5 \\
\hline Dy & 15.27 & 13.55 & 13.18 & 17.84 & 15.18 & 13.47 \\
\hline $\mathrm{Er}$ & 8.02 & 7.25 & 7.22 & 9.25 & 8.31 & 8.95 \\
\hline $\mathrm{Eu}$ & 1.69 & 1.82 & 2.4 & 3.51 & 1.73 & 2.68 \\
\hline $\mathrm{Gd}$ & 15.62 & 14.25 & 14.82 & 24.65 & 16.59 & 19.41 \\
\hline Ho & 2.89 & 2.62 & 2.73 & 3.17 & 2.9 & 2.72 \\
\hline $\mathrm{La}$ & 119.6 & 105.6 & 89 & 136.2 & 116.4 & 102.7 \\
\hline $\mathrm{Lu}$ & 0.99 & 0.97 & 0.96 & 1.25 & $<0.05$ & 1.18 \\
\hline $\mathrm{Nd}$ & 86.7 & 74.1 & 85.3 & 115.5 & 95.1 & 89.9 \\
\hline $\operatorname{Pr}$ & 24.29 & 20.55 & 22.79 & 29.66 & 26.38 & 24.44 \\
\hline $\mathrm{Sm}$ & 16.3 & 13.7 & 16.7 & 19.6 & 17.7 & 14.1 \\
\hline $\mathrm{Tb}$ & 2.56 & 2.22 & 2.19 & 3.54 & 2.32 & 2.64 \\
\hline $\mathrm{Tm}$ & 1.16 & 1.14 & 0.91 & 1.38 & 1.02 & 1.12 \\
\hline $\mathrm{Yb}$ & 7.2 & 7.3 & 6.4 & 7.5 & 7.5 & 7.5 \\
\hline
\end{tabular}




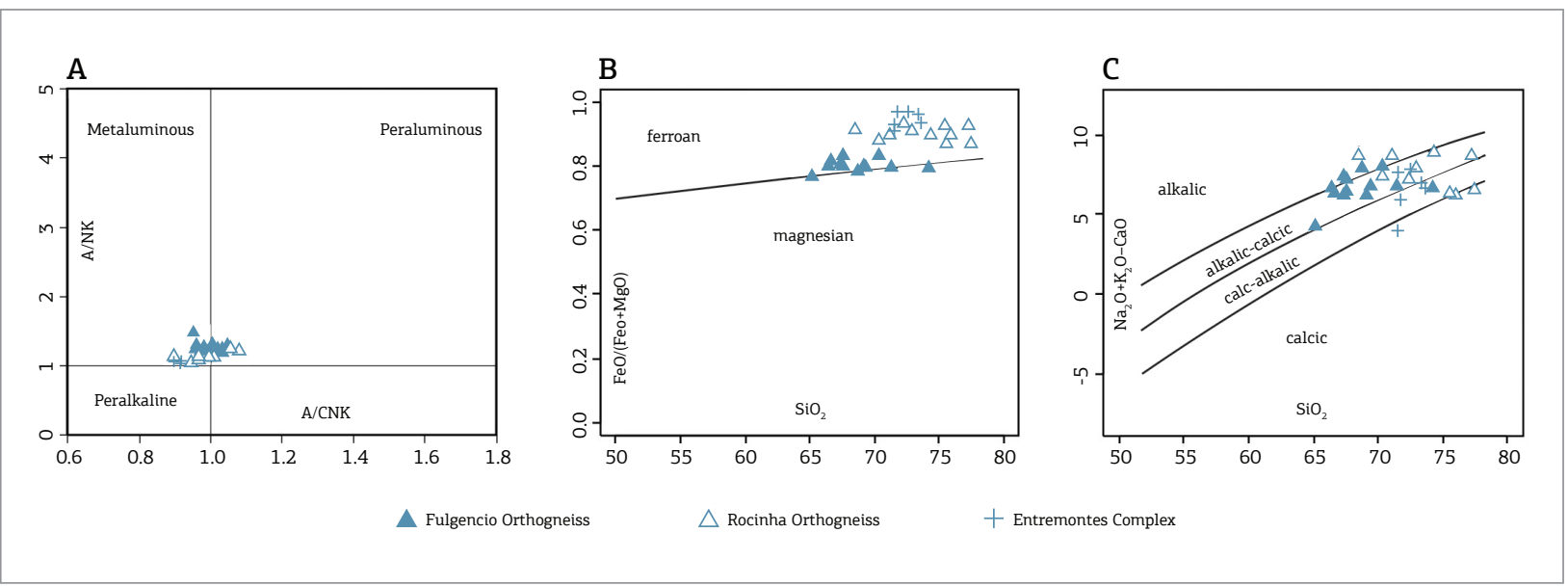

Figure 3. Lithogeochemical diagrams: (A) Diagram A/CNK versus A/NK (Shand 1943); (B and C) Major-element diagrams based on classification of granitoids (Frost et al. 2001).

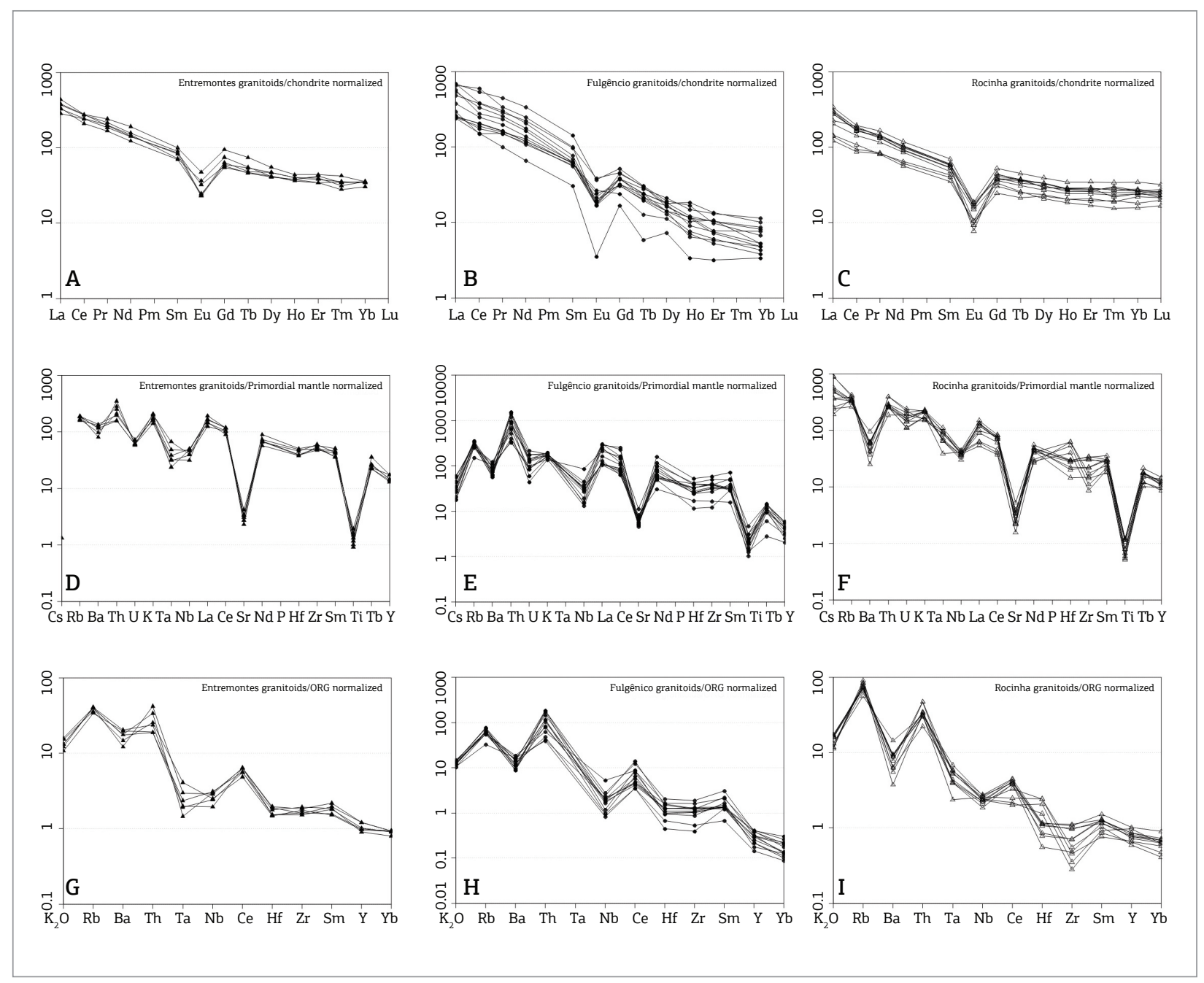

Figure 4. Multi-elemental diagrams: (A to C) REE diagrams (Boynton 1984); (D to F) Expanded diagrams normalized by primordial mantle (Wood et al. 1979); (G to I) Expanded diagrams normalized by ORG (Pearce et al. 1984) in order - Entremontes Complex, Fulgêncio Orthogneiss, and Rocinha Orthogneiss samples. 
garnet-muscovite-biotite granitic to granodioritic orthogneisses, locally containing K-feldspar augens and mafic xenoliths. They exhibit low angle foliation, with mineral stretching lineation generally oblique or perpendicular to the foliation plane. Metamorphic conditions were of the upper greenschist facies indicated by the presence of K-feldspar and biotite recrystallized and garnet. Compositionally, it is metaluminous to peraluminous and of medium-K calcalkaline nature.

\section{Rocinha Orthogneiss}

Rocinha Orthogneiss established by Cruz and Accioly (2013) consists of coarse- to medium-grained porphyroclastic to porphyroblastic granite, and the main mafic mineral is biotite, commonly displaying mylonitic features and metamorphosed under upper greenschist- to amphibolite-facies conditions indicated by deformation and recrystallization of K-feldspar and biotite. The geochemical analyzes show high $\mathrm{SiO}_{2}$ (Tab. 4) contents (77 to $68 \%$ ), K calc-alkaline to alkaline nature and metaluminous to slightly peraluminous chemical characteristics (Figs. 3A to 3C). Patterns in the primordial mantlenormalized (Wood et al. 1979) multi-element diagram (Fig. 4F) presents negative $\mathrm{Nb}$ anomalies, characteristically found in magmas sources modified by subduction, and also pronounced negative $\mathrm{Sr}$ and $\mathrm{Ti}$ anomalies and $\mathrm{Tb}$ and $\mathrm{Y}$ enrichment, a Ta-Nb depletion is observed in the Ocean Ridge Granites (ORG) -normalized spidergram (Pearce et al. 1984), as in Fig. 4I. The chondrite-normalized REE diagram (Boynton 1984), Fig. 4C, reveals flat HREE patterns and strong negative Eu anomalies, which are features similar to those of rocks formed in intra-plate settings. In the trace element diagrams of Pearce (1996) and Eby (1992), Figs. 5A to 5D, these rocks are similar to post-collisional/intra-plate rocks and A-type (A2) granites. The chemical signatures of Rocinha Orthogneiss suggest that the original magmas were formed in a post-collisional setting.

\section{Brasiliano granitoids}

Some additional granite bodies correlated to the Brasiliano Cycle were investigated in this study: Cryogenian-Ediacaran intrusions, among these are the equigranular medium- to fine-grained with muscovitebiotite or biotite-amphibole migmatitic granitic body with metasedimentary xenoliths exposed in Ibó, in Bahia state (Ibó migmatites); and the grey amphibole-biotite granitic augen-gneiss of Chorrochó and Abaré, Bahia state (Chorrochó augen-gneiss).

\section{ISOTOPIC DATA}

\section{$\mathrm{U}-\mathrm{Pb}$ Data}

$\mathrm{New} \mathrm{U}-\mathrm{Pb}$ data were acquired for this investigation. The results were used in combination with data obtained for the Salgueiro and Parnamirim mapping projects carried out by the Brazilian Geological Survey (CPRM) and they are available at http://geobank.sa.cprm.gov.br.

\section{Entremontes Complex}

The zircon grains from the sample of amphibole -bearing granitic gneiss dated in this study (RF-179Tab. 5) are prismatic with rounded edges, and they have an average aspect ratio of 3:1 (Fig. 6A). Many grains are strongly fractured and have abundant inclusion, thus rendering them not suitable for analysis. Some grains show subtle concentric or irregular zoning, and in others overgrowths and cores are recognized. A few grains of
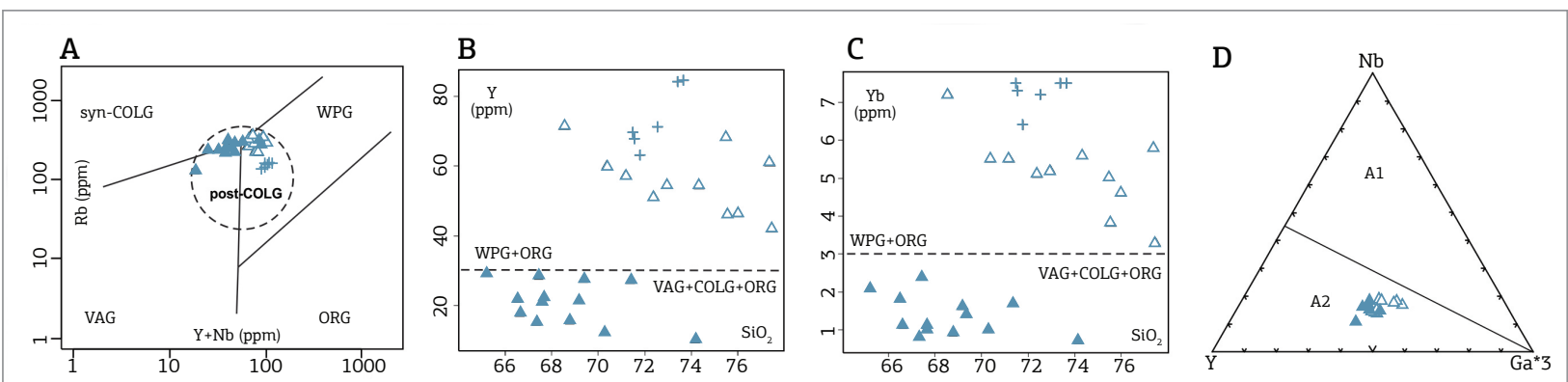

$\Delta$ Fulgencio Orthogneiss

$\triangle$ Rocinha Orthogneiss

+ Entremontes Complex

Figure 5. Lithogeochemical plots: (A) Geotectonic setting classification diagram by Pearce (1996); (B and C) by Eby (1992). Discriminate diagram of A-type granitoids (Eby 1992). 
Table 3. Geochemical data from Fulgêncio Orthogneiss.

\begin{tabular}{|c|c|c|c|c|c|c|c|c|}
\hline \multicolumn{9}{|c|}{ Fulgêncio Orthogneiss } \\
\hline SAMPLE & RF-287 & RF-288 & RF-289 & RF-328 & RF-267 & RF-292 & RF-240 & RF-241 \\
\hline \multicolumn{9}{|l|}{ Wt \% } \\
\hline $\mathrm{SiO}_{2}$ & 66.64 & 68.78 & 66.51 & 71.39 & 70.28 & 67.44 & 69.36 & 65.19 \\
\hline $\mathrm{TiO}_{2}$ & 0.49 & 0.26 & 0.57 & 0.4 & 0.36 & 0.54 & 0.79 & 1.19 \\
\hline $\mathrm{Al}_{2} \mathrm{O}_{3}$ & 13.36 & 14.83 & 13.45 & 12.91 & 13.86 & 13.63 & 15.14 & 14.84 \\
\hline $\mathrm{Fe}_{2} \mathrm{O}_{3}$ & 3.55 & 2.4 & 4.56 & 3.03 & 2.86 & 3.93 & 5.14 & 6.15 \\
\hline $\mathrm{CaO}$ & 1.74 & 1.32 & 1.7 & 1.3 & 0.98 & 1.33 & 2 & 3.09 \\
\hline $\mathrm{Cr}_{2} \mathrm{O}_{3}$ & $<0.01$ & $<0.01$ & $<0.01$ & $<0.01$ & $<0.01$ & $<0.01$ & $<0.01$ & $<0.01$ \\
\hline $\mathrm{K}_{2} \mathrm{O}$ & 5.04 & 5.88 & 5.44 & 5.07 & 5.96 & 5.59 & 5.32 & 4.12 \\
\hline $\mathrm{MgO}$ & 0.72 & 0.58 & 1 & 0.69 & 0.5 & 0.83 & 1.18 & 1.7 \\
\hline $\mathrm{MnO}$ & 0.04 & 0.03 & 0.06 & 0.03 & 0.03 & 0.04 & 0.06 & 0.08 \\
\hline $\mathrm{Na}_{2} \mathrm{O}$ & 3.08 & 3.45 & 2.92 & 2.96 & 3.14 & 3.21 & 3.51 & 3.36 \\
\hline $\mathrm{P}_{2} \mathrm{O}_{5}$ & 0.2 & 0.09 & 0.08 & $<0.01$ & 0.07 & 0.14 & 0.38 & 0.4 \\
\hline Sum & 0.19 & 0.21 & 0.12 & 0.37 & 0.13 & 0.25 & 0.38 & 0.38 \\
\hline LOI & 95.07 & 97.82 & 96.41 & 98.14 & 98.17 & 96.93 & 103.28 & 100.52 \\
\hline \multicolumn{9}{|l|}{ ppm } \\
\hline $\mathrm{Ba}$ & 436 & 616 & 477 & 557 & 437 & 495 & 709 & 932 \\
\hline $\mathrm{Be}$ & 1.5 & 1.6 & 2.4 & 2.3 & 2 & 1.4 & 6.4 & 3.3 \\
\hline Cs & 0.52 & 0.51 & 0.69 & 0.4 & 0.58 & 0.83 & 0.87 & 1.15 \\
\hline $\mathrm{Ga}$ & 21 & 19.1 & 20.9 & 17.7 & 19.7 & 20.1 & 23.8 & 24.9 \\
\hline $\mathrm{Hf}$ & 9.77 & 4.04 & 11.27 & 8.77 & 8.54 & 8.96 & 18.36 & 14.8 \\
\hline $\mathrm{Nb}$ & 20.17 & 9.31 & 17.91 & 9.86 & 11.94 & 18.87 & 28.04 & 53.26 \\
\hline $\mathrm{Rb}$ & 250 & 242 & 304 & 217 & 246 & 291 & 305.6 & 223.1 \\
\hline $\mathrm{Sn}$ & 2.6 & 4.3 & 7.2 & 1.9 & 3.4 & 3.3 & 1.4 & 3.3 \\
\hline Sr & 117 & 163 & 116 & 132 & 104 & 115 & 152.1 & 257.1 \\
\hline $\mathrm{Ta}$ & 1.09 & 0.45 & 1.09 & 0.69 & 0.86 & 1.55 & 0.94 & 1.37 \\
\hline Th & 84.2 & 38.3 & 147.1 & 93.7 & 134.9 & 66.1 & 146.5 & 49.9 \\
\hline $\mathrm{U}$ & 3.91 & 2.25 & 5.83 & 3.37 & 3.83 & 4.83 & 4.72 & 1.19 \\
\hline $\mathrm{W}$ & $<0.1$ & $<0.1$ & 2.6 & $<0.1$ & $<0.1$ & 0.6 & 1.2 & 0.1 \\
\hline $\mathrm{Y}$ & 17.56 & 15.35 & 21.66 & 27.03 & 12.38 & 28.23 & 27.46 & 29.14 \\
\hline $\mathrm{Zr}$ & 374 & 133 & 432 & 347 & 298 & 355 & 648.4 & 552.3 \\
\hline $\mathrm{Ag}$ & 0.02 & 0.02 & 0.05 & $<0.01$ & 0.06 & 0.01 & $<0.01$ & $<0.01$ \\
\hline $\mathrm{Au}$ & $<0.1$ & $<0.1$ & $<0.1$ & $<0.1$ & $<0.1$ & $<0.1$ & $<0.1$ & $<0.1$ \\
\hline As & $<1$ & $<1$ & $<1$ & $<1$ & $<1$ & $<1$ & 2 & $<1$ \\
\hline $\mathrm{Bi}$ & $<0.02$ & $<0.02$ & $<0.02$ & $<0.02$ & $<0.02$ & $<0.02$ & 0.02 & $<0.02$ \\
\hline $\mathrm{Cd}$ & 0.02 & 0.02 & $<0.01$ & 0.02 & 0.02 & $<0.01$ & 0.02 & 0.06 \\
\hline Co & 6.7 & 5.3 & 8.9 & 13.3 & 4.9 & 7 & 10 & 13.8 \\
\hline $\mathrm{Cu}$ & 25.4 & 23.6 & 27.7 & 5 & 149 & 16 & 50 & 39.4 \\
\hline $\mathrm{Hg}$ & $<0.01$ & $<0.01$ & $<0.01$ & $<0.01$ & $<0.01$ & $<0.01$ & 0.04 & $<0.01$ \\
\hline Mo & 0.58 & 0.67 & 2.84 & 0.8 & 1.08 & 0.43 & 0.98 & 0.69 \\
\hline $\mathrm{Ni}$ & 8.7 & 6.6 & 13.9 & 17.1 & 5.4 & 10.1 & 12.8 & 21.3 \\
\hline $\mathrm{Pb}$ & 4.8 & 5.5 & 2.6 & 4.6 & 8.1 & 3.3 & 6.7 & 5 \\
\hline $\mathrm{Sb}$ & $<0.05$ & $<0.05$ & $<0.05$ & $<0.05$ & $<0.05$ & $<0.05$ & $<0.05$ & $<0.05$ \\
\hline Se & $<1$ & $<1$ & $<1$ & $<1$ & $<1$ & $<1$ & 1 & $<1$ \\
\hline $\mathrm{Zn}$ & 54 & 45 & 62 & 41 & 37 & 56 & 73 & 94 \\
\hline $\mathrm{Ce}$ & 272.3 & 121 & 141.4 & 224.2 & 311.6 & 201.6 & 434.9 & 304.7 \\
\hline Dy & 5.71 & 4.17 & 5.34 & 5.88 & 4.52 & 6.76 & 6.24 & 5.73 \\
\hline $\mathrm{Er}$ & 1.58 & 1.27 & 2.18 & 2.14 & 1.21 & 2.74 & 2.06 & 2.83 \\
\hline $\mathrm{Eu}$ & 1.25 & 1.23 & 1.38 & 1.58 & 1.42 & 1.26 & 2.72 & 2.82 \\
\hline $\mathrm{Gd}$ & 9.62 & 8.05 & 8.31 & 9.88 & 9.96 & 9.77 & 13.43 & 11.92 \\
\hline Ho & 0.65 & 0.55 & 0.82 & 0.87 & 0.46 & 1.07 & 1.21 & 1.32 \\
\hline $\mathrm{La}$ & 168.4 & 91.6 & 80.7 & 178.9 & 215.2 & 117.6 & 215.4 & 150.9 \\
\hline $\mathrm{Lu}$ & 0.13 & 0.08 & 0.22 & 0.22 & 0.12 & 0.28 & 0.25 & 0.15 \\
\hline $\mathrm{Nd}$ & 107 & 65.1 & 68.2 & 98.8 & 124.8 & 83.3 & 203.3 & 134.6 \\
\hline $\operatorname{Pr}$ & 31.61 & 18.55 & 18.32 & 28.85 & 37.19 & 24.21 & 55.2 & 34.96 \\
\hline $\mathrm{Sm}$ & 13.5 & 11.2 & 10.9 & 12.1 & 15 & 12.5 & 27.8 & 19 \\
\hline $\mathrm{Tb}$ & 1.15 & 0.93 & 1.02 & 1.13 & 1.02 & 1.33 & 1.46 & 1.41 \\
\hline $\mathrm{Tm}$ & 0.19 & 0.15 & 0.26 & 0.26 & 0.13 & 0.38 & 0.21 & 0.22 \\
\hline $\mathrm{Yb}$ & 1.1 & 0.9 & 1.8 & 1.7 & 1 & 2.4 & 1.4 & 2.1 \\
\hline
\end{tabular}


Table 4. Geochemical data from Rocinha Orthogneiss.

\begin{tabular}{|c|c|c|c|c|c|c|c|c|c|c|c|}
\hline \multicolumn{12}{|c|}{ Rocinha Orthogneiss } \\
\hline SAMPLE & RF-323 & RF-323B & RF-323C & RF-466 & RF-467 & RF-311 & FL-180* & FL-181* & FL-185* & SF-182* & RF-033 \\
\hline \multicolumn{12}{|l|}{ Wt \% } \\
\hline $\mathrm{SiO}_{2}$ & 74.33 & 70.37 & 72.94 & 68.54 & 71.19 & 77.38 & 75.56 & 75.99 & 77.47 & 75.5 & 72.39 \\
\hline $\mathrm{TiO}_{2}$ & 0.3 & 0.29 & 0.15 & 0.29 & 0.31 & 0.17 & 0.14 & 0.2 & 0.27 & 0.13 & 0.2 \\
\hline $\mathrm{Al}_{2} \mathrm{O}_{3}$ & 13.4 & 13.06 & 11.82 & 13.43 & 13.19 & 12.15 & 11.8 & 11.83 & 12.5 & 11.12 & 11.06 \\
\hline $\mathrm{Fe}_{2} \mathrm{O}_{3}$ & 3.13 & 2.85 & 2.04 & 2.83 & 2.86 & 1.9 & 1.61 & 2.6 & 2.34 & 1.97 & 2.56 \\
\hline $\mathrm{CaO}$ & 0.78 & 1.71 & 0.77 & 0.74 & 0.92 & 0.68 & 0.95 & 1.05 & 1.23 & 0.66 & 0.8 \\
\hline $\mathrm{Cr}_{2} \mathrm{O}_{3}$ & $<0.01$ & $<0.01$ & $<0.01$ & $<0.01$ & $<0.01$ & $<0.01$ & $<0.01$ & $<0.01$ & $<0.01$ & $<0.01$ & $<0.01$ \\
\hline $\mathrm{K}_{2} \mathrm{O}$ & 6.82 & 6.49 & 6.33 & 6.47 & 6.96 & 6.63 & 4.77 & 4.73 & 5.3 & 4.53 & 5.27 \\
\hline $\mathrm{MgO}$ & 0.31 & 0.33 & 0.17 & 0.23 & 0.27 & 0.13 & 0.21 & 0.25 & 0.3 & 0.13 & 0.15 \\
\hline $\mathrm{MnO}$ & 0.04 & 0.04 & 0.03 & 0.04 & 0.04 & 0.01 & 0.05 & 0.06 & 0.04 & 0.05 & 0.05 \\
\hline $\mathrm{Na}_{2} \mathrm{O}$ & 2.86 & 2.7 & 2.48 & 3.05 & 2.68 & 2.73 & 2.63 & 2.62 & 2.62 & 2.58 & 2.79 \\
\hline $\mathrm{P}_{2} \mathrm{O}_{5}$ & $<0.01$ & $<0.01$ & 0.12 & $<0.01$ & $<0.01$ & $<0.01$ & 0.03 & 0.09 & 0.08 & 0.03 & 0.04 \\
\hline Sum & 0.19 & 0.29 & 0.41 & 0.23 & 0.16 & 0.23 & 0.17 & 0.08 & 0.23 & 0.52 & 0.04 \\
\hline LOI & 102.12 & 98.11 & 97.25 & 95.72 & 98.57 & 101.98 & 97.91 & 99.51 & 102.39 & 97.21 & 95.34 \\
\hline \multicolumn{12}{|l|}{ ppm } \\
\hline $\mathrm{Ba}$ & 453 & 466 & 280 & 443 & 475 & 323 & 315 & 393 & 461 & 188 & 721 \\
\hline $\mathrm{Be}$ & 4.6 & 3.6 & 3.2 & 6.3 & 3.8 & 3.8 & 5.3 & 5.5 & 3.9 & 3.8 & 4.5 \\
\hline Cs & 10 & 9.37 & 4.88 & 10.87 & 6.95 & 3.66 & 16.76 & 17.18 & 9.06 & 7.02 & 4.6 \\
\hline $\mathrm{Ga}$ & 20.5 & 20.4 & 19 & 22.1 & 20.4 & 19.6 & 21.1 & 22.2 & 21.8 & 23.4 & 18.6 \\
\hline $\mathrm{Hf}$ & 9.63 & 10.04 & 5.05 & 10.5 & 10.27 & 7.73 & 14 & 21.92 & 21.92 & 18.66 & 7.07 \\
\hline $\mathrm{Nb}$ & 26.91 & 23.47 & 18.64 & 27.63 & 22.56 & 21.01 & 24.35 & 25.88 & 22.57 & 23.7 & 25.52 \\
\hline $\mathrm{Rb}$ & 298 & 286 & 285 & 297 & 285 & 314 & 365 & 339 & 267 & 338 & 227.2 \\
\hline Sn & 7.1 & 9 & 6.4 & 11.4 & 7.8 & 11.4 & 7.4 & 8 & 4.5 & 8 & 4 \\
\hline $\mathrm{Sr}$ & 50.2 & 120 & 59.2 & 50.9 & 52.7 & 79.4 & 70.5 & 90 & 77 & 35.8 & 79.9 \\
\hline Ta & 4.79 & 4.13 & 2.79 & 4.02 & 2.86 & 2.79 & 4.12 & 3.66 & 3.06 & 3.78 & 1.67 \\
\hline Th & 25 & 26.8 & 24.6 & 27.7 & 27.8 & 37.9 & 17.9 & 38.1 & 24.1 & 26.3 & 25.2 \\
\hline $\mathrm{U}$ & 4.31 & 4.84 & 3.81 & 4.31 & 5.57 & 6.47 & 5.16 & 5.95 & 3.05 & 3.92 & 2.96 \\
\hline W & 2.6 & 4.5 & 4.2 & 1.7 & 4.5 & 0.4 & $<0.1$ & 1.5 & 1.1 & 0.2 & 0.5 \\
\hline Y & 54.22 & 60.06 & 54.35 & 71.24 & 57.22 & 60.77 & 46.1 & 46.34 & 41.83 & 68.2 & 51.03 \\
\hline $\mathrm{Zr}$ & 338 & 329 & 164 & 367 & 379 & 240 & 95.6 & 156 & 190 & 120 & 243.3 \\
\hline $\mathrm{Ag}$ & $<0.01$ & $<0.01$ & 0.04 & 0.02 & 0.03 & 0.06 & 0.16 & 0.15 & 0.08 & 0.12 & $<0.01$ \\
\hline $\mathrm{Au}$ & $<0.1$ & $<0.1$ & $<0.1$ & $<0.1$ & $<0.1$ & $<0.1$ & $<0.1$ & $<0.1$ & $<0.1$ & $<0.1$ & $<0.1$ \\
\hline As & $<1$ & $<1$ & $<1$ & $<1$ & $<1$ & $<1$ & $<1$ & $<1$ & 1 & 2 & $<1$ \\
\hline $\mathrm{Bi}$ & 0.06 & 0.08 & $<0.02$ & 0.08 & 0.06 & 0.04 & 0.39 & 0.49 & 0.12 & 0.69 & 0.05 \\
\hline $\mathrm{Cd}$ & $<0.01$ & $<0.01$ & $<0.01$ & 0.01 & $<0.01$ & 0.03 & 0.03 & 0.09 & 0.04 & $<0.1$ & 0.03 \\
\hline Co & 2.3 & 2.2 & 1.2 & 2.9 & 2.3 & 0.8 & 1.6 & 2.4 & 2.7 & 1.4 & 1.5 \\
\hline $\mathrm{Cu}$ & 2 & 2.5 & 2.5 & 16.8 & 6.9 & 5.3 & 6.7 & 9.2 & 6.7 & 5.2 & 3 \\
\hline $\mathrm{Hg}$ & $<0.01$ & $<0.01$ & $<0.01$ & $<0.01$ & $<0.01$ & $<0.01$ & $<0.01$ & $<0.01$ & 0.02 & $<0.01$ & 0.02 \\
\hline Mo & 0.23 & 0.25 & 0.53 & 2.31 & 0.98 & 1.24 & 0.32 & 0.69 & 0.39 & 0.31 & 0.65 \\
\hline $\mathrm{Ni}$ & 1.7 & 2.1 & 2.2 & 5.6 & 2.1 & 1.4 & 2.2 & 2.9 & 3 & 2.2 & 1.4 \\
\hline $\mathrm{Pb}$ & 5.9 & 7 & 7 & 7.3 & 5.7 & 4.8 & 2.5 & 4.3 & 23.4 & 5.8 & 3.3 \\
\hline $\mathrm{Sb}$ & $<0.05$ & $<0.05$ & $<0.05$ & 0.22 & 0.07 & $<0.05$ & 0.07 & 0.08 & $<0.05$ & 0.07 & $<0.05$ \\
\hline $\mathrm{Se}$ & $<1$ & $<1$ & $<1$ & $<1$ & $<1$ & 1 & $<1$ & $<1$ & $<1$ & 1 & 1 \\
\hline $\mathrm{Zn}$ & 48 & 49 & 23 & 52 & 46 & 30 & 29 & 48 & 41 & 39 & 56 \\
\hline $\mathrm{Ce}$ & 138.8 & 144.1 & 134.2 & 157.8 & 145.2 & 133.2 & 75.8 & 87.5 & 116 & 70.6 & 152.7 \\
\hline Dy & 9.56 & 10.65 & 10.05 & 12.7 & 10.65 & 10.79 & 7.56 & 7.19 & 6.67 & 8.7 & 9.36 \\
\hline $\mathrm{Er}$ & 5.52 & 5.81 & 5.45 & 7.32 & 6.07 & 6.07 & 4.11 & 4.35 & 3.59 & 5.11 & 6.01 \\
\hline $\mathrm{Eu}$ & 1.3 & 1.22 & 0.77 & 1.38 & 1.18 & 0.57 & 0.68 & 0.78 & 1.1 & 0.68 & 1.36 \\
\hline $\mathrm{Gd}$ & 9.73 & 11.56 & 10.09 & 13.63 & 11.37 & 10.76 & 7.89 & 6.35 & 8.73 & 9.38 & 9.82 \\
\hline Ho & 1.97 & 2 & 1.86 & 2.47 & 2 & 2.03 & 1.46 & 1.47 & 1.33 & 1.74 & 2.08 \\
\hline $\mathrm{La}$ & 85.7 & 95.7 & 85.8 & 106.1 & 92 & 92 & 43.4 & 45 & 63.8 & 37.8 & 70.2 \\
\hline $\mathrm{Lu}$ & 0.88 & 0.83 & 0.69 & 1.03 & 0.76 & 0.8 & 0.64 & 0.69 & 0.54 & 0.75 & 0.83 \\
\hline $\mathrm{Nd}$ & 54.7 & 61.4 & 56 & 71.8 & 62.5 & 59.1 & 36.6 & 34.2 & 51.9 & 38.9 & 63.3 \\
\hline $\mathrm{Pr}$ & 16.2 & 17.66 & 16.33 & 20.23 & 17.8 & 17.17 & 10.33 & 9.83 & 14.32 & 10.06 & 16.86 \\
\hline $\mathrm{Sm}$ & 10.4 & 11.2 & 10.5 & 13.7 & 11.6 & 11.4 & 7.8 & 6.9 & 9.3 & 8.4 & 11.8 \\
\hline $\mathrm{Tb}$ & 1.72 & 1.73 & 1.6 & 2.12 & 1.78 & 1.76 & 1.19 & 1.01 & 1.22 & 1.47 & 1.79 \\
\hline $\mathrm{Tm}$ & 0.97 & 0.93 & 0.81 & 1.11 & 0.88 & 0.88 & 0.63 & 0.61 & 0.5 & 0.75 & 0.71 \\
\hline $\mathrm{Yb}$ & 5.6 & 5.5 & 5.2 & 7.2 & 5.5 & 5.8 & 3.8 & 4.6 & 3.3 & 5 & 5.1 \\
\hline
\end{tabular}


zircon are homogeneous and these were analyzed with spots concentrated in the cores. The U-Pb analyses indicate a crystallization age of 2,734 $\pm 11 \mathrm{Ma}$ (Fig. 6B).

\section{Fulgêncio Orthogneiss}

The investigated sample is a granitic gneiss (sample RF-243), as in Tab. 6. The BSE and CL images show abundant zircon crystals with concentric oscillatory zoning and thin (between 10 to $50 \mathrm{~mm}$ ) overgrowths (Figs. 7A to 7C). The U-Pb results indicated an age of 1,996 $\pm 8 \mathrm{Ma}$ (Fig. 7D). No significant differences were found between the ages of core and rims of zircons crystals analyses. Fulgêncio Orthogneiss has, therefore, a Paleoproterozoic granite protolith, which is slightly younger than others generated during Paleoproterozoic orogenesis within Borborema Province.

Table 5. Isotopic data from Entremontes Complex zircons (sample RF-179), Universidade Federal do Rio Grande do Sul data isotope laboratory.

\begin{tabular}{|c|c|c|c|c|c|c|c|c|c|c|c|c|c|c|c|}
\hline \multirow{2}{*}{$\begin{array}{l}\text { RF-179 } \\
\text { Spot } n^{\circ}\end{array}$} & \multicolumn{2}{|c|}{ Ratios } & \multicolumn{13}{|c|}{ Ages (Ma) } \\
\hline & $\%^{206} \mathrm{~Pb}$ & ${ }^{232} \mathrm{Th} /{ }^{238} \mathrm{U}$ & ${ }^{207} \mathrm{~Pb} /{ }^{206} \mathrm{~Pb}$ & $1 s(\%)$ & ${ }^{207} \mathrm{~Pb} /{ }^{235} \mathrm{U}$ & $1 s(\%)$ & ${ }^{206} \mathrm{~Pb} /{ }^{238} \mathrm{U}$ & $1 \mathrm{~s}(\%)$ & ${ }^{207} \mathrm{~Pb} /{ }^{206} \mathrm{~Pb}$ & $1 \mathrm{~s}(\mathrm{Ma})$ & ${ }^{207} \mathrm{~Pb} /{ }^{235} \mathrm{U}$ & $1 \mathrm{~s}(\mathrm{Ma})$ & ${ }^{206} \mathrm{~Pb} /{ }^{238} \mathrm{U}$ & $1 \mathrm{~s}(\mathrm{Ma})$ & $\begin{array}{c}\text { Conc } \\
\text { (\%) }\end{array}$ \\
\hline MT65_08_a & 0.02 & 0.14 & 0.18852 & 0.7 & 13.8064 & 1.3 & 0.53116 & 1.0 & 2729 & 11 & 2737 & 12 & 2746 & 23 & 101 \\
\hline MT65_08_b & 0.04 & 0.18 & 0.18564 & 0.7 & 12.2151 & 2.3 & 0.47723 & 2.2 & 2704 & 11 & 2621 & 21 & 2515 & 45 & 93 \\
\hline MT65_16_a & 0.03 & 0.15 & 0.19160 & 0.7 & 13.4383 & 1.4 & 0.50869 & 1.2 & 2756 & 12 & 2711 & 13 & 2651 & 26 & 96 \\
\hline MT65_23 & 0.00 & 0.13 & 0.18717 & 0.8 & 13.0380 & 1.3 & 0.50522 & 1.0 & 2717 & 13 & 2682 & 12 & 2636 & 22 & 97 \\
\hline MT65_37 & 0.02 & 0.11 & 0.19039 & 0.7 & 14.9269 & 2.9 & 0.56863 & 2.8 & 2746 & 11 & 2811 & 27 & 2902 & 65 & 106 \\
\hline MT65_38 & 0.14 & 0.12 & 0.18644 & 1.0 & 13.3200 & 1.4 & 0.51816 & 1.0 & 2711 & 16 & 2703 & 13 & 2691 & 22 & 99 \\
\hline MT65_39 & 0.03 & 0.49 & 0.18257 & 0.9 & 10.9878 & 6.0 & 0.43649 & 5.9 & 2676 & 14 & 2522 & 56 & 2335 & 116 & 87 \\
\hline MT65_47 & 0.03 & 0.16 & 0.18769 & 0.6 & 13.1696 & 1.3 & 0.50889 & 1.1 & 2722 & 10 & 2692 & 12 & 2652 & 24 & 97 \\
\hline MT65_55 & 0.03 & 0.13 & 0.18890 & 0.8 & 11.9820 & 2.2 & 0.46004 & 2.1 & 2733 & 13 & 2603 & 21 & 2440 & 42 & 89 \\
\hline
\end{tabular}
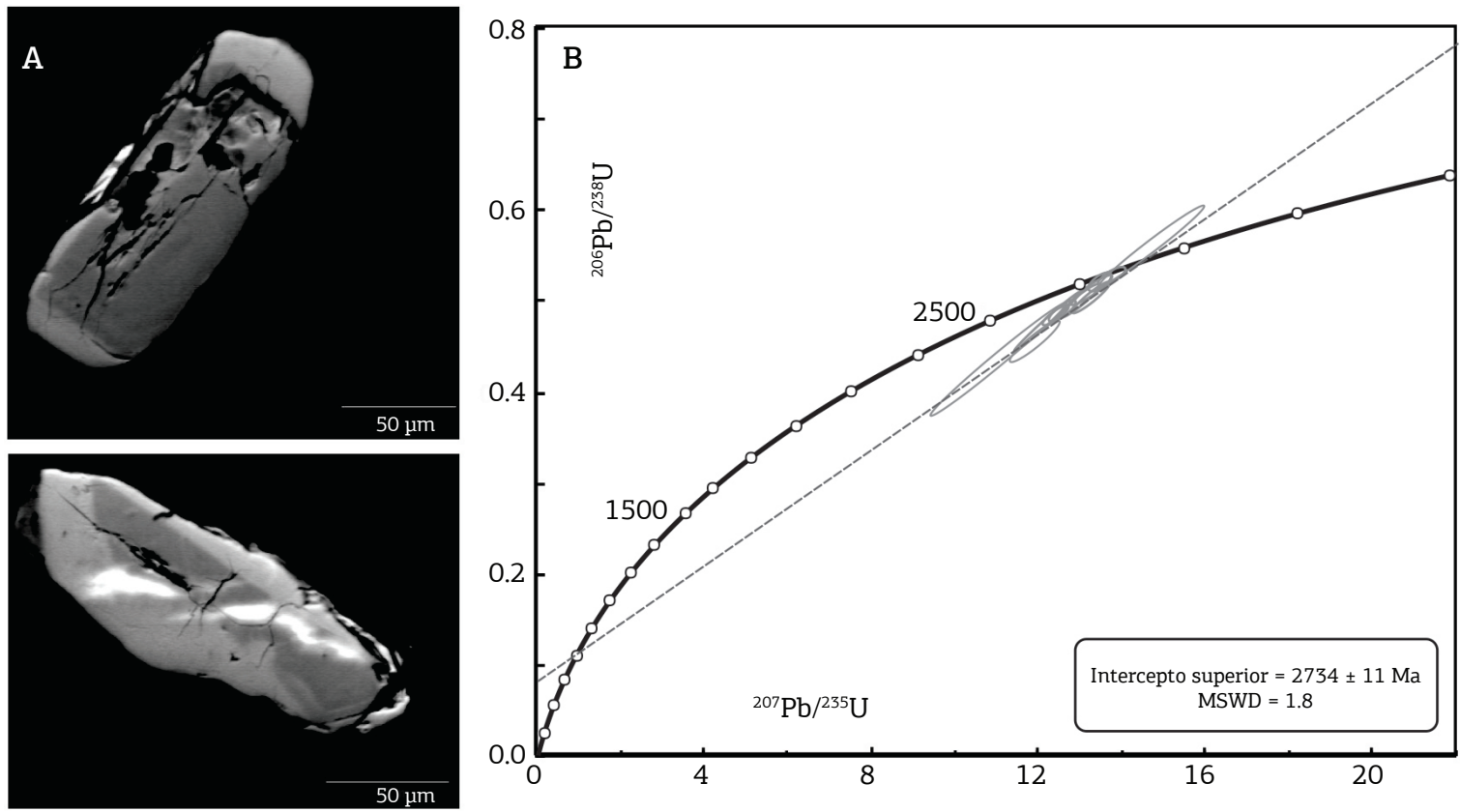

Figure 6. Geochronological data for zircon grains from the Entremontes Complex. (A) Backscattering images of zircon grains with sizes from small to medium, prismatic with rounded edges and a predominant proportion $3 \times 1$; (B) U-Pb zircon Concordia diagram. 


\section{Riacho Seco Gneissic-migmatitic Complex}

Riacho Seco Gneissic-migmatitic Complex sample is a medium-grained equi-granular biotite granite-gneiss (sample RF-111). Zircons from this sample are rather heterogeneous in terms of shape and size, with elongated prismatic crystals, as well as rounded ones with concentric zoning. Overgrowths and corrosion features are therefore recognized (Figs. $8 \mathrm{~A}$ to $8 \mathrm{D}$ ). The $\mathrm{U}-\mathrm{Pb}$ results are complex and difficult to interpret due to the variety of ages found for the different zircon populations (Tab. 7). Three major age groups are identified: 1,992 $\pm 27 ; 2,461 \pm 24$ and 2,704 $\pm 12 \mathrm{Ma}$ (Figs. 9A to 9C), the first two discords show Neoproterozoic lower intercept ages $(548 \pm 76 \mathrm{Ma}$ and $559 \pm 40 \mathrm{Ma})$. In homogeneous crystals, Paleoproterozoic ages predominate, whereas in the heterogeneous crystals Archean ages are more seen with a few exceptions. Two zircon grains analyzed have differences in ages between core and rim, with Archean age in the core $(2,526$ to $2,711 \mathrm{Ga})$ and Paleoproterozoic age on the edge (2,003 to $2100 \mathrm{Ga})$. The age patterns of Riacho Seco Complex suggest that its igneous protoliths are the product of anatexis of Archean continental crust indicated by the abundant presence of inherited archean zircons.

\section{Lobo Orthogneiss}

Lobo Orthogneiss (Brito \& Freitas 2011), recognized during Salgueiro mapping project, was dated by the U-Pb LA-ICPMS method on zircon at $994 \pm 25$ Ma (Brito \& Marinho 2012). One additional sample of a granodiorite mylonite (sample RF-270) was dated (Tab. 8) and yielded a U-Pb zircon age of $974 \pm 8 \mathrm{Ma}$

Table 6. Isotopic data from Fulgêncio Orthogneiss zircons (sample RF-243), UNB data isotope laboratory.

\begin{tabular}{|c|c|c|c|c|c|c|c|c|c|c|c|c|c|c|c|c|c|}
\hline \multirow{2}{*}{$\begin{array}{l}\text { RF-243 } \\
\text { Spot } n^{\circ}\end{array}$} & \multirow[b]{2}{*}{$\%^{206} \mathrm{~Pb}$} & \multicolumn{2}{|c|}{$\begin{array}{c}\text { Contents } \\
\text { (ppm) }\end{array}$} & \multicolumn{7}{|c|}{ Ratios } & \multicolumn{7}{|c|}{ Ages (Ma) } \\
\hline & & $\mathrm{U}$ & Th & ${ }^{232} \mathrm{Th} /{ }^{238} \mathrm{U}$ & ${ }^{207} \mathrm{~Pb} /{ }^{206} \mathrm{~Pb}$ & $1 s(\%)$ & ${ }^{207} \mathrm{~Pb} /{ }^{235} \mathrm{U}$ & $1 s(\%)$ & ${ }^{206} \mathrm{~Pb} /{ }^{238} \mathrm{U}$ & $1 \mathrm{~s}(\%)$ & ${ }^{207} \mathrm{~Pb} /{ }^{206} \mathrm{~Pb}$ & $1 \mathrm{~s}(\mathrm{Ma})$ & ${ }^{207} \mathrm{~Pb} /{ }^{235} \mathrm{U}$ & $1 \mathrm{~s}(\mathrm{Ma})$ & ${ }^{206} \mathrm{~Pb} /{ }^{238} \mathrm{U}$ & $1 \mathrm{~s}(\mathrm{Ma})$ & Conc (\%) \\
\hline 006-Z03 & 0.00 & 105 & 45 & 0.43 & 0.12203 & 0.3 & 5.8279 & 0.6 & 0.34636 & 0.6 & 1986 & 6 & 1951 & 6 & 1917 & 9 & 97 \\
\hline 010-Z05 & 0.01 & 93 & 35 & 0.38 & 0.12471 & 0.6 & 5.8422 & 1.1 & 0.33976 & 0.9 & 2025 & 10 & 1953 & 9 & 1886 & 15 & 93 \\
\hline 011-Z06 & 0.51 & 259 & 76 & 0.29 & 0.12495 & 0.6 & 5.8089 & 0.8 & 0.33718 & 0.5 & 2028 & 10 & 1948 & 7 & 1873 & 9 & 92 \\
\hline 012-Z07 & 0.00 & 105 & 45 & 0.43 & 0.12308 & 0.4 & 6.3994 & 0.8 & 0.37710 & 0.7 & 2001 & 7 & 2032 & 7 & 2063 & 12 & 103 \\
\hline 013-Z08 & 0.02 & 148 & 32 & 0.21 & 0.12269 & 0.6 & 6.2300 & 0.9 & 0.36827 & 0.6 & 1996 & 11 & 2009 & 7 & 2021 & 10 & 101 \\
\hline 014-Z09 & 0.00 & 93 & 35 & 0.38 & 0.12276 & 0.4 & 6.3961 & 0.7 & 0.37787 & 0.5 & 1997 & 7 & 2032 & 6 & 2066 & 9 & 103 \\
\hline 019-Z11 & 0.00 & 148 & 32 & 0.21 & 0.12291 & 0.5 & 6.0520 & 0.7 & 0.35712 & 0.6 & 1999 & 8 & 1983 & 6 & 1968 & 10 & 98 \\
\hline 020-Z12 & 0.01 & 93 & 35 & 0.38 & 0.12242 & 0.5 & 5.8440 & 1.0 & 0.34623 & 0.8 & 1992 & 8 & 1953 & 8 & 1917 & 14 & 96 \\
\hline $021-\mathrm{Z} 13 \mathrm{~N}$ & 0.01 & 259 & 76 & 0.29 & 0.12252 & 0.4 & 6.1428 & 0.8 & 0.36362 & 0.7 & 1993 & 7 & 1996 & 7 & 1999 & 11 & 100 \\
\hline 022-Z13B & 0.01 & 105 & 45 & 0.43 & 0.12163 & 0.5 & 5.7957 & 0.8 & 0.34558 & 0.7 & 1980 & 10 & 1946 & 7 & 1913 & 11 & 97 \\
\hline $023-Z 14 N$ & 0.01 & 148 & 32 & 0.21 & 0.12256 & 0.8 & 6.0070 & 1.1 & 0.35549 & 0.7 & 1994 & 14 & 1977 & 10 & 1961 & 13 & 98 \\
\hline 025-Z15 & 0.11 & 259 & 76 & 0.29 & 0.12137 & 0.5 & 5.8478 & 1.0 & 0.34945 & 0.9 & 1976 & 8 & 1954 & 9 & 1932 & 15 & 98 \\
\hline 026-Z16B & 0.00 & 105 & 45 & 0.43 & 0.12128 & 1.2 & 5.9997 & 1.4 & 0.35880 & 0.8 & 1975 & 21 & 1976 & 12 & 1976 & 13 & 100 \\
\hline 031-Z17 & 0.00 & 93 & 35 & 0.38 & 0.12300 & 0.5 & 6.1247 & 0.9 & 0.36114 & 0.8 & 2000 & 9 & 1994 & 8 & 1988 & 14 & 99 \\
\hline 032-Z18B & 0.28 & 259 & 76 & 0.29 & 0.12156 & 0.5 & 5.4826 & 0.9 & 0.32710 & 0.7 & 1979 & 8 & 1898 & 8 & 1824 & 12 & 92 \\
\hline 033-Z18N & 0.01 & 105 & 45 & 0.43 & 0.11967 & 0.6 & 6.0576 & 1.3 & 0.36713 & 1.2 & 1951 & 11 & 1984 & 11 & 2016 & 20 & 103 \\
\hline 035-Z20 & 0.07 & 93 & 35 & 0.38 & 0.11963 & 1.7 & 5.6153 & 1.9 & 0.34042 & 0.8 & 1951 & 30 & 1918 & 16 & 1889 & 13 & 97 \\
\hline 036-Z21 & 0.19 & 259 & 76 & 0.29 & 0.12006 & 0.4 & 5.6883 & 0.9 & 0.34361 & 0.8 & 1957 & 8 & 1930 & 8 & 1904 & 13 & 97 \\
\hline $040-\mathrm{Z} 22 \mathrm{~N}$ & 0.02 & 148 & 32 & 0.21 & 0.12223 & 0.7 & 6.1913 & 1.2 & 0.36739 & 1.0 & 1989 & 12 & 2003 & 10 & 2017 & 17 & 101 \\
\hline 041-Z23B & 0.22 & 93 & 35 & 0.38 & 0.12395 & 0.9 & 6.0320 & 1.5 & 0.35294 & 1.2 & 2014 & 16 & 1980 & 13 & 1949 & 21 & 97 \\
\hline $042-\mathrm{Z} 23 \mathrm{~N}$ & 0.23 & 259 & 76 & 0.29 & 0.12146 & 0.5 & 5.5772 & 1.0 & 0.33302 & 0.8 & 1978 & 10 & 1913 & 8 & 1853 & 13 & 94 \\
\hline 043-Z24 & 0.01 & 105 & 45 & 0.43 & 0.12021 & 0.5 & 5.9925 & 1.0 & 0.36154 & 0.8 & 1959 & 10 & 1975 & 8 & 1989 & 14 & 102 \\
\hline 045-Z26 & 0.00 & 93 & 35 & 0.38 & 0.12319 & 0.4 & 6.1753 & 0.8 & 0.36356 & 0.7 & 2003 & 7 & 2001 & 7 & 1999 & 12 & 100 \\
\hline 046-Z27 & 0.00 & 259 & 76 & 0.29 & 0.12264 & 0.3 & 6.0005 & 0.7 & 0.35485 & 0.6 & 1995 & 6 & 1976 & 6 & 1958 & 9 & 98 \\
\hline 049-Z28B & 0.01 & 105 & 45 & 0.43 & 0.12248 & 0.3 & 5.9105 & 0.7 & 0.34999 & 0.6 & 1993 & 6 & 1963 & 6 & 1935 & 10 & 97 \\
\hline 051-Z29B & 0.00 & 93 & 35 & 0.38 & 0.11917 & 0.4 & 5.3140 & 0.8 & 0.32342 & 0.7 & 1944 & 8 & 1871 & 7 & 1806 & 10 & 93 \\
\hline 052-Z29N & 0.01 & 259 & 76 & 0.29 & 0.11805 & 0.4 & 4.8465 & 1.2 & 0.29774 & 1.2 & 1927 & 8 & 1793 & 10 & 1680 & 17 & 87 \\
\hline 053-Z3OB & 0.18 & 105 & 45 & 0.43 & 0.12271 & 0.5 & 5.9061 & 0.9 & 0.34907 & 0.7 & 1996 & 9 & 1962 & 8 & 1930 & 12 & 97 \\
\hline 054-Z30N & 0.06 & 148 & 32 & 0.21 & 0.12388 & 0.8 & 5.8866 & 1.1 & 0.34465 & 0.7 & 2013 & 15 & 1959 & 10 & 1909 & 12 & 95 \\
\hline 053-Z30B & 0.18 & 259 & 76 & 0.29 & 0.12271 & 0.5 & 5.9061 & 0.9 & 0.34907 & 0.7 & 1996 & 9 & 1962 & 8 & 1930 & 12 & 97 \\
\hline 054-Z30N & 0.06 & 105 & 45 & 0.43 & 0.12388 & 0.5 & 5.8866 & 0.9 & 0.34465 & 0.7 & 2013 & 8 & 1959 & 8 & 1909 & 12 & 95 \\
\hline 055-Z31 & 0.00 & 148 & 32 & 0.21 & 0.12295 & 0.6 & 6.0402 & 0.9 & 0.35631 & 0.6 & 1999 & 11 & 1982 & 8 & 1965 & 11 & 98 \\
\hline
\end{tabular}



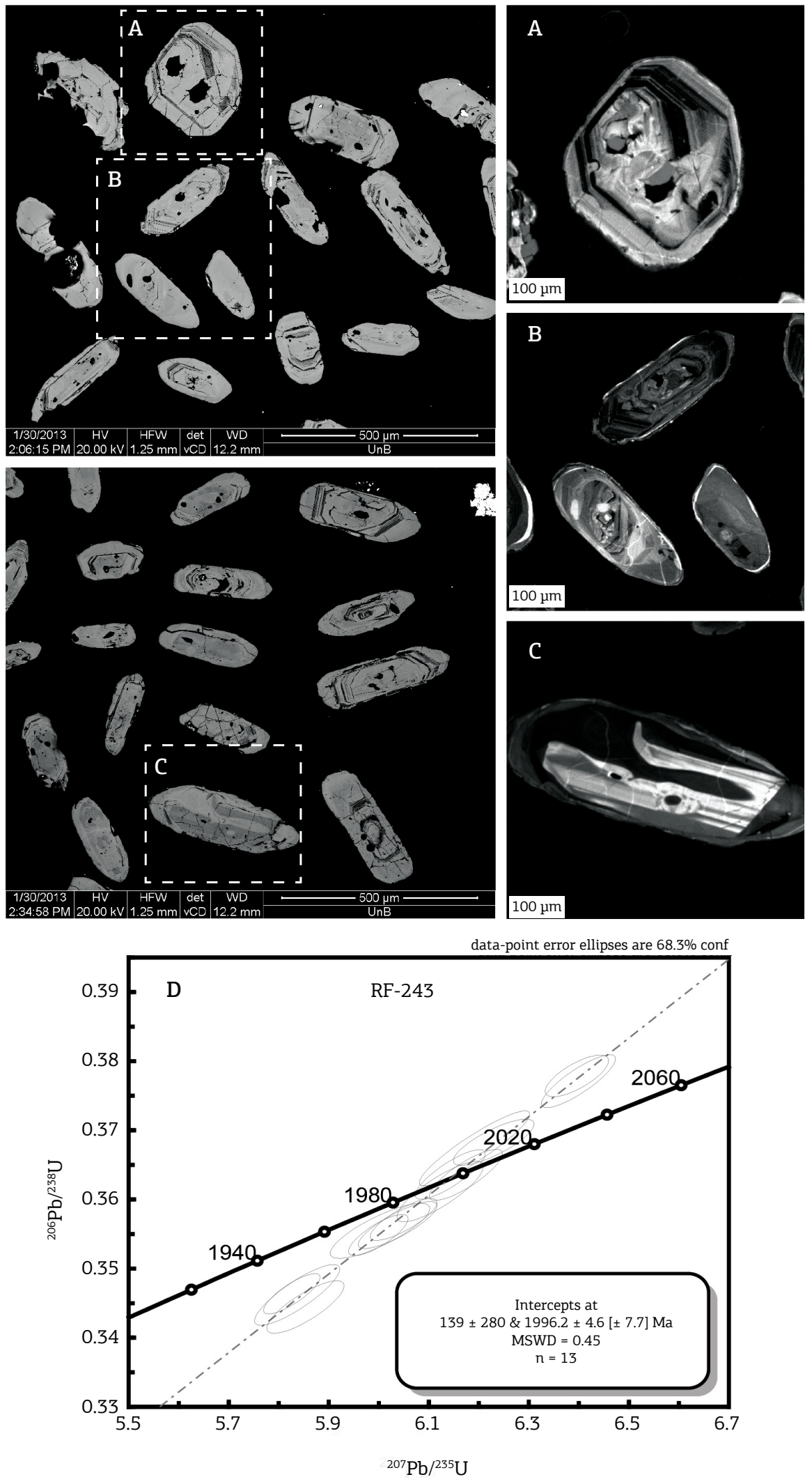

Figure 7. Results of zircons analyzes from Fulgêncio Orthogneiss. Backscatter electron images left with details of crystals imaged by cathodoluminescence at right. (A) Image of zircon with metamictic core and rim zoned;

(B) Crystals showing oscillatory zoning besides crystal homogeneous; (C) Prismatic crystal with irregular nucleus;

(D) Concordia diagram highlighting the Orosirian age unit. 

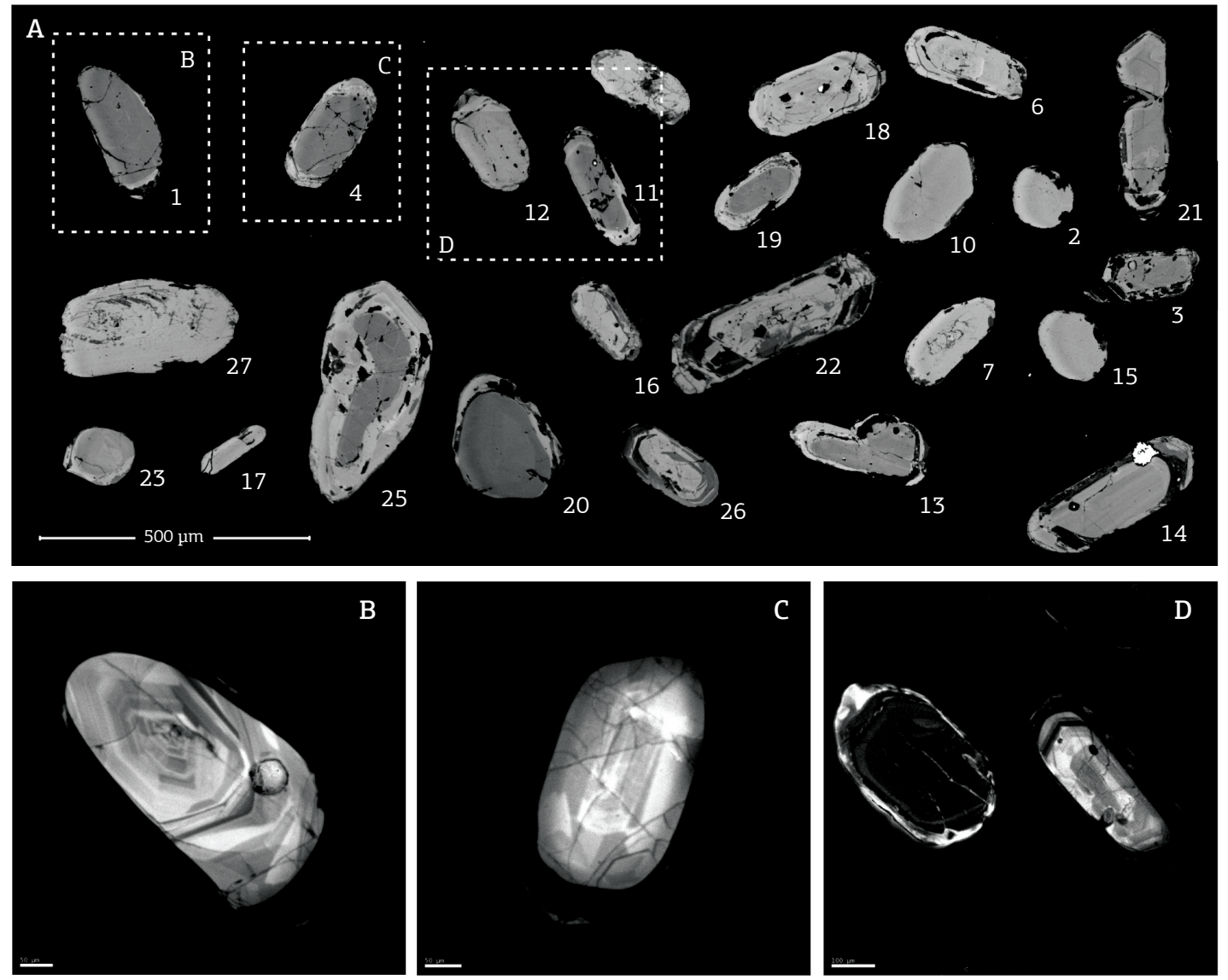

Figure 8. Zircons microscope images from granitic orthogneiss sample (RF-111), Riacho Seco Gneissic-migmatitic Complex. (A) Backscatter images of some zircons grains from Riacho Seco Complex sample (RF-111); (B to D) Cathodoluminescence images showing different features on zircon grains, with elongated prismatic crystals, others rounded and showing concentric zoning, overgrowths and corrosion features are recognized in some grains.

Table 7. Isotopic data from Riacho Seco Gnaissic-migmatitic Complex (sample RF-111), UNB data isotope laboratory.

\begin{tabular}{|c|c|c|c|c|c|c|c|c|c|c|c|c|c|c|c|c|c|}
\hline \multirow{2}{*}{$\begin{array}{l}\text { RF-111 } \\
\text { Spot } n^{\circ}\end{array}$} & \multirow[b]{2}{*}{$\%^{206} \mathrm{~Pb}$} & \multicolumn{2}{|c|}{$\begin{array}{c}\text { Contents } \\
\text { (ppm) }\end{array}$} & \multicolumn{7}{|c|}{ Ratios } & \multicolumn{7}{|c|}{ Ages (Ma) } \\
\hline & & $\mathrm{U}$ & Th & ${ }^{232} \mathrm{Th} /{ }^{238} \mathrm{U}$ & ${ }^{207} \mathrm{~Pb} /{ }^{206} \mathrm{~Pb}$ & $1 \mathrm{~s}(\%)$ & ${ }^{207} \mathrm{~Pb} /{ }^{235} \mathrm{U}$ & $1 \mathrm{~s}(\%)$ & ${ }^{206} \mathrm{~Pb} /{ }^{238} \mathrm{U}$ & $1 s(\%)$ & ${ }^{207} \mathrm{~Pb} /{ }^{206} \mathrm{~Pb}$ & $1 \mathrm{~s}(\mathrm{Ma})$ & ${ }^{207} \mathrm{~Pb} /{ }^{235} \mathrm{U}$ & $1 \mathrm{~s}(\mathrm{Ma})$ & ${ }^{206} \mathrm{~Pb} /{ }^{238} \mathrm{U}$ & $1 \mathrm{~s}(\mathrm{Ma})$ & Conc (\%) \\
\hline 004-Z01 & 0.01 & 93 & 35 & 0.38 & 0.18568 & 0.6 & 13.2410 & 0.9 & 0.51721 & 0.8 & 2704 & 9 & 2697 & 9 & 2687 & 17 & 99 \\
\hline 005-Z02 & 0.50 & 259 & 76 & 0.29 & 0.08956 & 2.1 & 2.1598 & 2.4 & 0.17489 & 1.1 & 1416 & 40 & 1168 & 16 & 1039 & 10 & 73 \\
\hline 006-Z03 & 0.73 & 105 & 45 & 0.43 & 0.16841 & 0.6 & 9.2062 & 1.8 & 0.39648 & 1.7 & 2542 & 10 & 2359 & 17 & 2153 & 32 & 85 \\
\hline 007-Z04 & 0.04 & 148 & 32 & 0.21 & 0.18232 & 2.0 & 7.4191 & 3.1 & 0.29513 & 2.4 & 2674 & 32 & 2163 & 28 & 1667 & 36 & 62 \\
\hline 008-Z05 & 0.21 & 93 & 35 & 0.38 & 0.12053 & 0.4 & 5.8244 & 1.0 & 0.35048 & 0.9 & 1964 & 8 & 1950 & 9 & 1937 & 15 & 99 \\
\hline 010-Z07 & 0.17 & 105 & 45 & 0.43 & 0.10822 & 0.8 & 3.1963 & 1.7 & 0.21421 & 1.5 & 1770 & 15 & 1456 & 13 & 1251 & 17 & 71 \\
\hline 013-Z08 & 0.20 & 148 & 32 & 0.21 & 0.11741 & 0.6 & 4.4552 & 1.8 & 0.27522 & 1.7 & 1917 & 10 & 1723 & 15 & 1567 & 24 & 82 \\
\hline 014-Z09 & 0.04 & 93 & 35 & 0.38 & 0.11099 & 0.5 & 3.8159 & 1.2 & 0.24935 & 1.1 & 1816 & 9 & 1596 & 10 & 1435 & 14 & 79 \\
\hline 015-Z10 & 0.00 & 259 & 76 & 0.29 & 0.12293 & 0.6 & 6.4063 & 1.1 & 0.37795 & 0.9 & 1999 & 11 & 2033 & 9 & 2067 & 15 & 103 \\
\hline 016-Z11 & 0.35 & 105 & 45 & 0.43 & 0.18141 & 0.5 & 10.6838 & 1.5 & 0.42714 & 1.4 & 2666 & 8 & 2496 & 14 & 2293 & 28 & 86 \\
\hline 017-Z12 & 0.01 & 148 & 32 & 0.21 & 0.15743 & 0.7 & 9.0012 & 0.9 & 0.41467 & 0.6 & 2428 & 12 & 2338 & 8 & 2236 & 11 & 92 \\
\hline $018-Z 13 N$ & 0.13 & 93 & 35 & 0.38 & 0.16683 & 1.4 & 8.9837 & 1.9 & 0.39056 & 1.3 & 2526 & 23 & 2336 & 17 & 2125 & 24 & 84 \\
\hline 019-Z13B & 0.07 & 259 & 76 & 0.29 & 0.13013 & 0.7 & 3.7196 & 1.3 & 0.20731 & 1.1 & 2100 & 13 & 1576 & 10 & 1214 & 12 & 58 \\
\hline 020-Z14 & 0.20 & 105 & 45 & 0.43 & 0.17081 & 0.8 & 10.7499 & 2.4 & 0.45646 & 2.3 & 2566 & 13 & 2502 & 22 & 2424 & 46 & 94 \\
\hline 026-Z16 & 0.16 & 259 & 76 & 0.29 & 0.11277 & 0.8 & 4.1028 & 1.9 & 0.26386 & 1.7 & 1845 & 14 & 1655 & 15 & 1510 & 23 & 82 \\
\hline 027-Z17 & 0.11 & 105 & 45 & 0.43 & 0.16034 & 0.9 & 7.4905 & 2.9 & 0.33882 & 2.8 & 2459 & 15 & 2172 & 26 & 1881 & 45 & 76 \\
\hline 028-Z18 & 0.00 & 148 & 32 & 0.21 & 0.16050 & 1.9 & 10.4418 & 2.3 & 0.47185 & 1.2 & 2461 & 33 & 2475 & 21 & 2492 & 25 & 101 \\
\hline 030-Z19N & 0.01 & 259 & 76 & 0.29 & 0.18641 & 1.4 & 12.6794 & 1.8 & 0.49333 & 1.2 & 2711 & 22 & 2656 & 17 & 2585 & 26 & 95 \\
\hline 029-Z19B & 0.06 & 93 & 35 & 0.38 & 0.12319 & 1.6 & 3.3622 & 3.3 & 0.19794 & 2.9 & 2003 & 28 & 1496 & 25 & 1164 & 31 & 58 \\
\hline 034-Z20 & 0.00 & 148 & 32 & 0.21 & 0.18511 & 0.5 & 12.8634 & 0.8 & 0.50398 & 0.6 & 2699 & 9 & 2670 & 8 & 2631 & 13 & 97 \\
\hline 035-Z21 & 0.24 & 93 & 35 & 0.38 & 0.18400 & 0.7 & 10.5409 & 1.7 & 0.41548 & 1.6 & 2689 & 11 & 2484 & 16 & 2240 & 30 & 83 \\
\hline
\end{tabular}



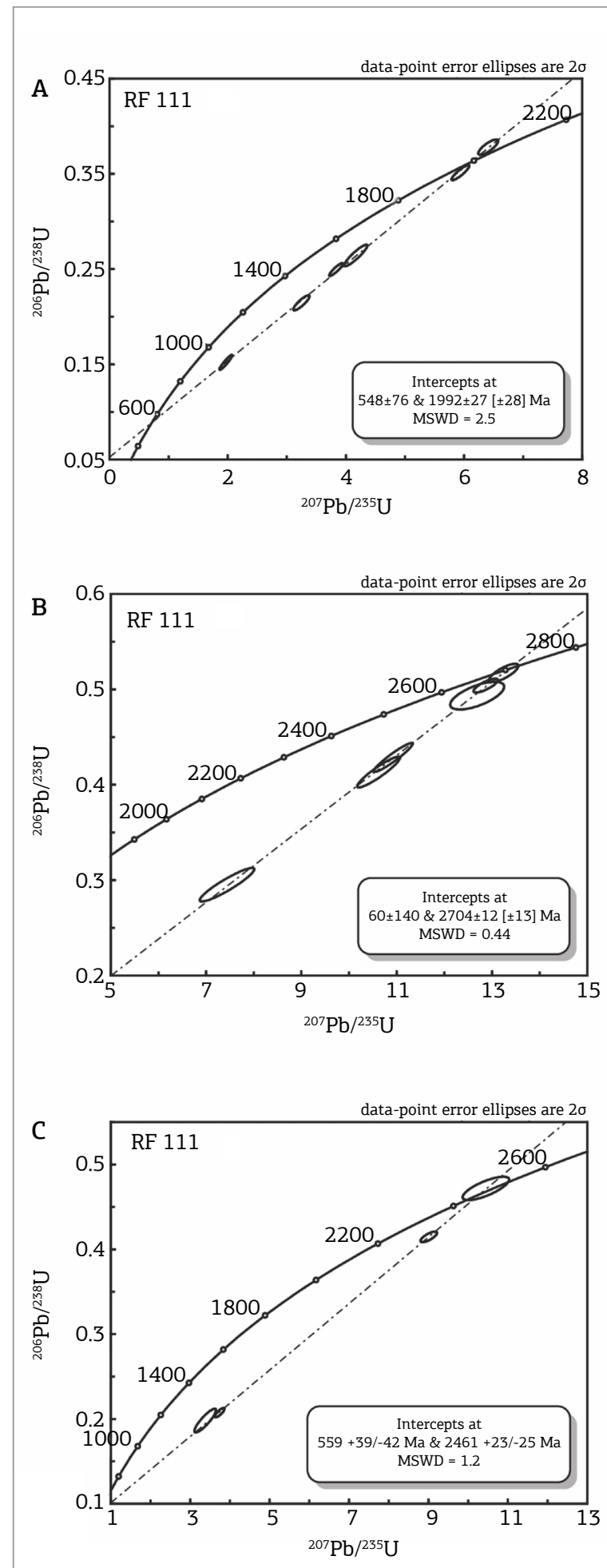

Figure 9. Concordia diagrams for zircon grains from granitic orthogneiss sample $\mathrm{RF}-111$, showing tree different age groups. (A) Concord diagram with majority of zircon grains being of Paleoproterozoic (Orosirian) age; (B) Concordia diagram for the second zircon population with Neoarchean age; (C) Concordia diagram for small-zircon populations that yielded Siderian (Paleoproterozoic) ages.
(Fig. 10B) interpreted as the crystallization age of the protolith. Zircons showing Stenian periods are also observed in this sample. The crystals are predominantly prismatic; some grains show homogenous texture and narrow zoned edges and others show oscillatory concentric zoning, no significant differences ages were found between spots on core and rim (Fig. 10A). Data indicate that the granite/granodiorite protolith of Lobo Orthogneiss crystallized during the Cariris Velhos Event and probably suffered shear deformation during the Brasiliano Orogeny.

\section{Rocinha Orthogneiss}

Sample RF-323 of Rocinha Orthogneiss (Cruz \& Accioly 2013) was investigated. The zircon grains are prismatic, with rounded edges and aspect ratios ranging from 2:1 to 4:1. The elongated grains have reddish color and some inclusions, whereas the smaller ones tend to be pink. The BSE images show predominance of homogeneous grains, although some thin overgrowths are observed (Fig. 11A). Some crystals showing cores and wider "porous" rims may suggest an alteration process (Figs. 9C to 9D). One sample collected from the type locality of Rocinha Orthogneiss is dated (RF-323) (Tab. 9), and the analyses indicate a concordia age of $956 \pm 2 \mathrm{Ma}$ (Fig. 11B).

\section{Nd Isotopes}

$\mathrm{Sm}-\mathrm{Nd}$ analyses were carried out on 23 whole-rock samples (Tab. 10, Fig. 12). Considering the $\mathrm{Nd}$ isotopic results, combined with field observations, geochemical and geochronological data, six main groups of granitoids are identified:

- Neoproterozoic intrusions or Brasiliano granitoids (Ediacaran-Criogenian) comprising Bendó Orthogneiss (sample RF-415, model age of 1.79 $\mathrm{Ga}$ and $\mathrm{e}_{\mathrm{Nd}}-600 \mathrm{Ma}-$ of -9.97), Ibó Migmatites with medium grained biotite-amphibole migmatite including metasedimentary xenoliths (sample RF-022, model age of $1.43 \mathrm{Ga}$ and $\mathrm{e}_{\mathrm{Nd}}-600 \mathrm{Ma}$ - of -4.23), and grey granitic migmatite with muscovite and biotite and metasedimentary xenoliths (sample RF-068, model age of $1.88 \mathrm{Ga}$ and $\mathrm{e}_{\mathrm{Nd}}-$ $600 \mathrm{Ma}$ - of -6.09), Chorrochó Augen-gneiss (sample RF-027, model age of $1.25 \mathrm{Ga}$ and $\mathrm{e}_{\mathrm{Nd}}-600$ $\mathrm{Ma}-$ of -2.80), and fine grained biotite-amphibole orthogneiss (sample RF-322, model age of $1.54 \mathrm{Ga}$ and $\mathrm{e}_{\mathrm{Nd}}-600 \mathrm{Ma}-$ of -4.16).

- Cariris Velhos granites (Tonian-Estenian), which comprise granitic migmatite (sample RF-003, model age of $1.37 \mathrm{Ga}$ and $\mathrm{e}_{\mathrm{Nd}}-1 \mathrm{Ga}-$ of +0.64$)$, the 
coarse grained granite gneiss of Rocinha Orthogneiss (sample RF-010, model age of $1.46 \mathrm{Ga}$ and $\mathrm{e}_{\mathrm{Nd}}-1$ $\mathrm{Ga}-$ of +0.63 , sample RF-033, model age of 1.56 and $\mathrm{e}_{\mathrm{Nd}}(1 \mathrm{Ga})$ of -1.29 , sample RF-323, model age of 1,45 and $e_{\mathrm{Nd}}(1 \mathrm{Ga})$ of -0.32). The granodioritic mylonitic gneiss from Lobo Orthogneiss (sample RF-270, model age of $1.54 \mathrm{Ga}$ and $\mathrm{e}_{\mathrm{Nd}}$ (1 Ga) of -1.23).

- Paleoproterozoic granites of PEAL, which corresponds to Fulgêncio Orthogneiss. Three different facies were investigated: augen-gneiss (sample RF-243, model age of $2.55 \mathrm{Ga}$ and $\mathrm{e}_{\mathrm{Nd}}(2 \mathrm{Ga})$ of -5.55$)$, fine grained granitic gneiss (sample RF-244, model age of $2.79 \mathrm{Ga}$ and $\mathrm{e}_{\mathrm{Nd}}$ ( $2 \mathrm{Ga}$ ) of -10.06), and coarse grained granitic migmatite (sample RF-267, model age of $2.49 \mathrm{Ga}$ and $\mathrm{e}_{\mathrm{Nd}}(2$ $\mathrm{Ga}$ ) of -5.52; sample RF-040, model age of 2.68 and $\mathrm{e}_{\mathrm{Nd}}$ (2 Ga) of -6.80; sample RF-165, model age of $2.60 \mathrm{Ga}$ and $\mathrm{e}_{\mathrm{Nd}}(2 \mathrm{Ga})$ of -6.18$)$.

- Paleoproterozoic granitoids from RSN, comprising metamorphosed granites and amphibolites from Riacho Seco Gneissic-migmatitic Complex, represented by: medium grained equigranular granite gneiss (sample RF-111, model age of $3.14 \mathrm{Ga}$ and $\mathrm{e}_{\mathrm{Nd}}(2$ $\mathrm{Ga})$ of -13.30) and coarse grained granite gneiss (sample RF-136, model age of 3.14 and $\mathrm{e}_{\mathrm{Nd}}(2 \mathrm{Ga})$ of -14.02). Other units recognized in the RSN are the Caraíbas Migmatite with two samples of granitic

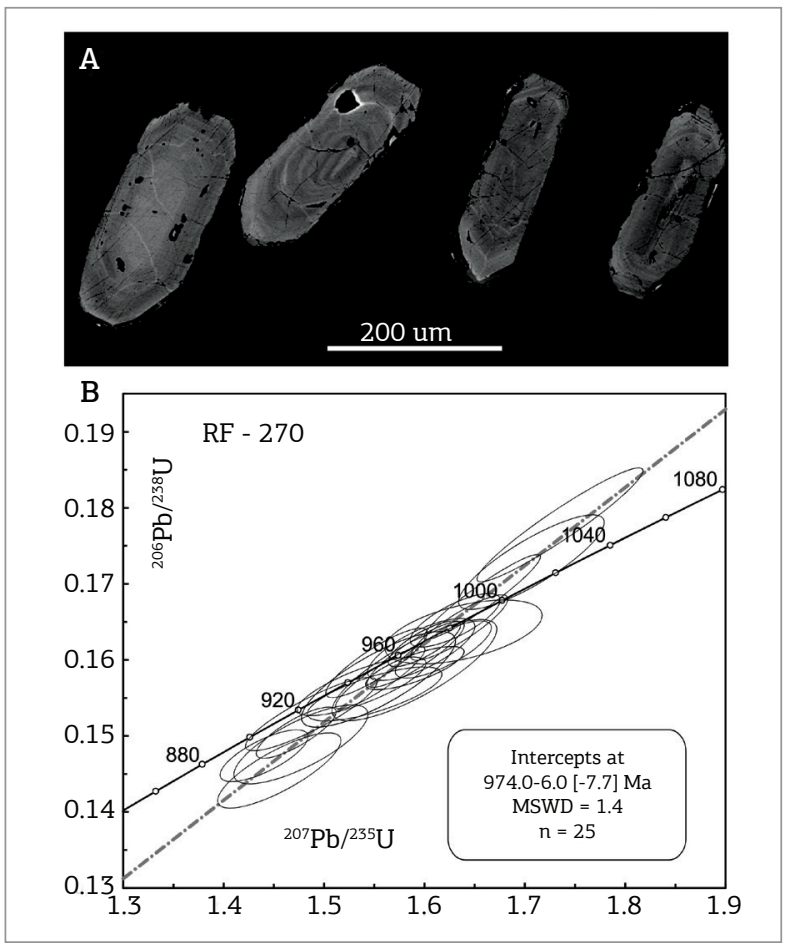

Figure 10. U-Pb data from sample RF-270 for the Lobo Orthogneiss. (A) Backscatter images for some of the analyzed zircon grains, some grains show homogenous texture and narrow zoned edges, and others present oscillatory concentric zoning, no significant differences in age were found between spots on core and rim; (B) $\mathrm{U}-\mathrm{Pb}$ zircon age Concordia diagram.

Table 8. Isotopic data from Lobo Orthogneiss zircons (sample RF-270), UNB data isotope laboratory.

\begin{tabular}{|c|c|c|c|c|c|c|c|c|c|c|c|c|c|c|c|c|c|}
\hline \multirow{2}{*}{$\begin{array}{l}\text { RF-270 } \\
\text { Spot } n^{\circ}\end{array}$} & \multirow[b]{2}{*}{$\%^{206} \mathrm{~Pb}$} & \multicolumn{2}{|c|}{$\begin{array}{c}\text { Contents } \\
\text { (ppm) }\end{array}$} & \multicolumn{7}{|c|}{ Ratios } & \multicolumn{7}{|c|}{ Ages (Ma) } \\
\hline & & U & Th & ${ }^{232} \mathrm{Th} /{ }^{238} \mathrm{U}$ & ${ }^{207} \mathrm{~Pb} /{ }^{206} \mathrm{~Pb}$ & $1 \mathrm{~s}(\%)$ & ${ }^{207} \mathrm{~Pb} /{ }^{235} \mathrm{U}$ & $1 \mathrm{~s}(\%)$ & ${ }^{206} \mathrm{~Pb} /{ }^{238} \mathrm{U}$ & $1 \mathrm{~s}(\%)$ & ${ }^{207} \mathrm{~Pb} /{ }^{206} \mathrm{~Pb}$ & $1 \mathrm{~s}(\mathrm{Ma})$ & ${ }^{207} \mathrm{~Pb} /{ }^{235} \mathrm{U}$ & $1 \mathrm{~s}(\mathrm{Ma})$ & ${ }^{206} \mathrm{~Pb} /{ }^{238} \mathrm{U}$ & $1 \mathrm{~s}(\mathrm{Ma})$ & Conc (\%) \\
\hline 006-Z03 & 0.02 & 105 & 45 & 0.43 & 0.07181 & 0.6 & 1.5913 & 1.2 & 0.16072 & 1.1 & 980 & 12 & 967 & 8 & 961 & 10 & 98 \\
\hline 008-Z05 & 0.01 & 93 & 35 & 0.38 & 0.07159 & 0.5 & 1.5560 & 1.2 & 0.15764 & 1.1 & 974 & 10 & 953 & 7 & 944 & 9 & 97 \\
\hline 009-Z06 & 0.04 & 259 & 76 & 0.29 & 0.07099 & 0.6 & 1.4723 & 1.1 & 0.15043 & 0.9 & 957 & 13 & 919 & 7 & 903 & 8 & 94 \\
\hline 014-Z09 & 0.02 & 93 & 35 & 0.38 & 0.07277 & 0.7 & 1.6189 & 1.2 & 0.16136 & 1.0 & 1007 & 15 & 978 & 8 & 964 & 9 & 96 \\
\hline 015-Z10 & 0.01 & 259 & 76 & 0.29 & 0.07158 & 0.7 & 1.6306 & 1.1 & 0.16521 & 0.9 & 974 & 14 & 982 & 7 & 986 & 8 & 101 \\
\hline 018-Z12B & 0.02 & 93 & 35 & 0.38 & 0.07160 & 1.2 & 1.5543 & 2.0 & 0.15744 & 1.6 & 975 & 24 & 952 & 12 & 943 & 14 & 97 \\
\hline 020-Z14 & 0.01 & 105 & 45 & 0.43 & 0.07157 & 0.5 & 1.5999 & 0.9 & 0.16212 & 0.8 & 974 & 11 & 970 & 6 & 969 & 7 & 99 \\
\hline 023-Z15 & 0.02 & 148 & 32 & 0.21 & 0.07258 & 1.0 & 1.5905 & 1.3 & 0.15893 & 0.7 & 1002 & 21 & 966 & 8 & 951 & 6 & 95 \\
\hline 018-Z12B & 0.02 & 93 & 35 & 0.38 & 0.07160 & 1.2 & 1.5543 & 2.0 & 0.15744 & 1.6 & 975 & 24 & 952 & 12 & 943 & 14 & 97 \\
\hline 020-Z14 & 0.01 & 105 & 45 & 0.43 & 0.07157 & 0.5 & 1.5999 & 0.9 & 0.16212 & 0.8 & 974 & 11 & 970 & 6 & 969 & 7 & 99 \\
\hline 023-Z15 & 0.02 & 148 & 32 & 0.21 & 0.07258 & 1.0 & 1.5905 & 1.3 & 0.15893 & 0.7 & 1002 & 21 & 966 & 8 & 951 & 6 & 95 \\
\hline 028-Z20 & 0.02 & 93 & 35 & 0.38 & 0.07054 & 0.6 & 1.5524 & 1.3 & 0.15961 & 1.2 & 944 & 13 & 951 & 8 & 955 & 10 & 101 \\
\hline 029-Z21 & 0.05 & 259 & 76 & 0.29 & 0.07088 & 0.8 & 1.4404 & 1.2 & 0.14739 & 0.9 & 954 & 17 & 906 & 7 & 886 & 8 & 93 \\
\hline 030-Z22 & 0.01 & 105 & 45 & 0.43 & 0.07144 & 0.5 & 1.6575 & 1.4 & 0.16828 & 1.4 & 970 & 9 & 992 & 9 & 1003 & 13 & 103 \\
\hline 037-Z26 & 0.04 & 148 & 32 & 0.21 & 0.07124 & 1.4 & 1.5375 & 1.7 & 0.15652 & 1.0 & 964 & 28 & 945 & 10 & 937 & 9 & 97 \\
\hline 039-Z28 & 0.04 & 259 & 76 & 0.29 & 0.07263 & 1.6 & 1.6390 & 2.0 & 0.16367 & 1.0 & 1004 & 33 & 985 & 12 & 977 & 9 & 97 \\
\hline 043-Z30 & 0.03 & 148 & 32 & 0.21 & 0.07056 & 1.3 & 1.4873 & 1.8 & 0.15288 & 1.3 & 945 & 26 & 925 & 11 & 917 & 11 & 97 \\
\hline 044-Z31 & 0.03 & 93 & 35 & 0.38 & 0.07177 & 0.9 & 1.5968 & 1.4 & 0.16137 & 1.0 & 979 & 18 & 969 & 9 & 964 & 9 & 98 \\
\hline 052-Z36 & 0.01 & 105 & 45 & 0.43 & 0.07218 & 0.6 & 1.6347 & 1.2 & 0.16425 & 1.1 & 991 & 11 & 984 & 8 & 980 & 10 & 99 \\
\hline 054-Z38 & 0.04 & 93 & 35 & 0.38 & 0.07195 & 1.2 & 1.4771 & 1.8 & 0.14889 & 1.4 & 985 & 24 & 921 & 11 & 895 & 12 & 91 \\
\hline 055-Z39 & 0.03 & 259 & 76 & 0.29 & 0.07258 & 1.0 & 1.4555 & 1.7 & 0.14545 & 1.4 & 1002 & 21 & 912 & 10 & 875 & 11 & 87 \\
\hline 057-Z41 & 0.01 & 148 & 32 & 0.21 & 0.07079 & 0.9 & 1.7350 & 1.9 & 0.17776 & 1.7 & 951 & 19 & 1022 & 13 & 1055 & 17 & 111 \\
\hline 059-Z43 & 0.03 & 259 & 76 & 0.29 & 0.07269 & 1.2 & 1.5900 & 2.1 & 0.15864 & 1.7 & 1005 & 25 & 966 & 13 & 949 & 15 & 94 \\
\hline 064-Z45n & 0.02 & 148 & 32 & 0.21 & 0.07231 & 1.5 & 1.5505 & 1.8 & 0.15552 & 0.9 & 995 & 30 & 951 & 11 & 932 & 8 & 94 \\
\hline 084-Z61 & 0.02 & 93 & 35 & 0.38 & 0.07160 & 0.9 & 1.7065 & 1.7 & 0.17286 & 1.5 & 975 & 19 & 1011 & 11 & 1028 & 14 & 105 \\
\hline
\end{tabular}




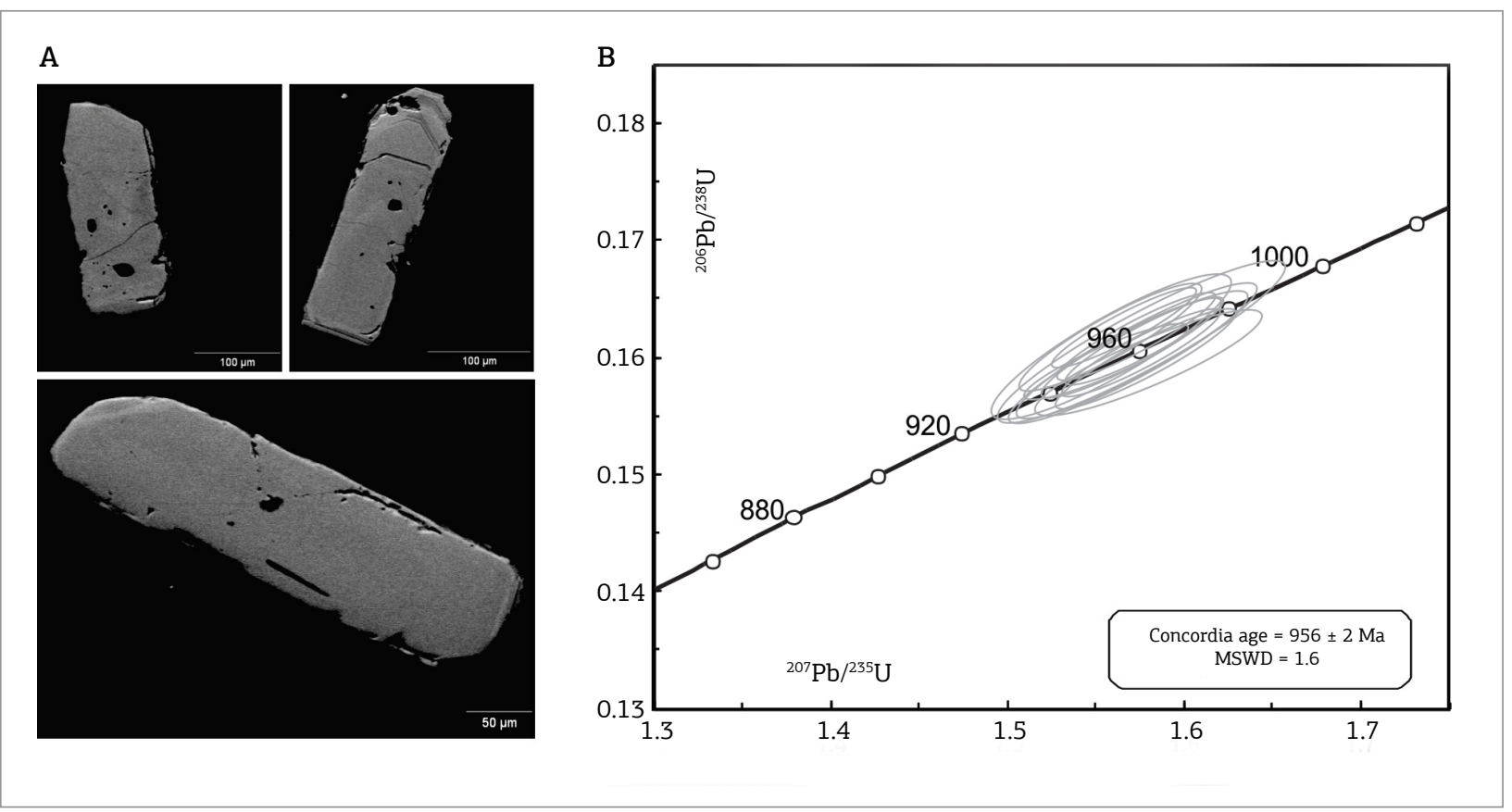

Figure 11. Geochronological data analysis sample of Rocinha Orthogneiss. (A) Backscatter electron images illustrating the predominant characteristics of the analyzed zircons, prismatic and homogeneous crystals, with the presence of narrow zoned edges; (B) Concordia diagram for zircon from the Rocinha Orthogneiss sample.

Table 9. Isotopic data from Rocinha Orthogneiss zircons (sample RF-323), Universidade Federal do Rio Grande do Sul data isotope laboratory.

\begin{tabular}{|c|c|c|c|c|c|c|c|c|c|c|c|c|c|c|c|}
\hline \multirow{2}{*}{$\begin{array}{l}\text { RF-323 } \\
\text { Spot } n^{\circ}\end{array}$} & \multirow[b]{2}{*}{$\%^{206} \mathrm{~Pb}$} & \multicolumn{6}{|c|}{ Ratios } & \multicolumn{8}{|c|}{ Ages (Ma) } \\
\hline & & ${ }^{232} \mathrm{Th} /{ }^{238} \mathrm{U}$ & ${ }^{207} \mathrm{~Pb} /{ }^{206} \mathrm{~Pb}$ & $1 s(\%)$ & ${ }^{207} \mathrm{~Pb} /{ }^{235} \mathrm{U}$ & $1 s(\%)$ & ${ }^{206} \mathrm{~Pb} /{ }^{38} \mathrm{U}$ & $\begin{array}{l}1 \mathrm{~s} \\
(\%)\end{array}$ & ${ }^{207} \mathrm{~Pb} /{ }^{206} \mathrm{~Pb}$ & $1 \mathrm{~s}(\mathrm{Ma})$ & ${ }^{207} \mathrm{~Pb} /{ }^{235} \mathrm{U}$ & $1 \mathrm{~s}(\mathrm{Ma})$ & ${ }^{206} \mathrm{~Pb} /{ }^{238} \mathrm{U}$ & $1 \mathrm{~s}(\mathrm{Ma})$ & $\begin{array}{c}\text { Conc } \\
(\%)\end{array}$ \\
\hline MT32_01 & 0.06 & 0.21 & 0.07109 & 0.7 & 1.54777 & 1.2 & 0.15791 & 0.9 & 960 & 15 & 950 & 7 & 945 & 8 & 98 \\
\hline MT32_08 & 0.04 & 0.16 & 0.07113 & 0.7 & 1.60268 & 1.4 & 0.16343 & 1.2 & 961 & 14 & 971 & 9 & 976 & 11 & 102 \\
\hline MT32_10 & 0.06 & 0.21 & 0.07004 & 0.7 & 1.55387 & 1.3 & 0.16089 & 1.0 & 930 & 15 & 952 & 8 & 962 & 9 & 103 \\
\hline MT32_20 & 0.04 & 0.23 & 0.07059 & 0.6 & 1.56495 & 1.2 & 0.16078 & 1.1 & 946 & 11 & 956 & 8 & 961 & 10 & 102 \\
\hline MT32_21 & 0.03 & 0.27 & 0.07073 & 0.5 & 1.53479 & 1.0 & 0.15738 & 0.8 & 950 & 11 & 944 & 6 & 942 & 7 & 99 \\
\hline MT32_23 & 0.06 & 0.21 & 0.07124 & 0.7 & 1.58430 & 1.4 & 0.16130 & 1.3 & 964 & 14 & 964 & 9 & 964 & 11 & 100 \\
\hline MT32_27 & 0.02 & 0.24 & 0.07061 & 0.6 & 1.53077 & 1.0 & 0.15724 & 0.8 & 946 & 12 & 943 & 6 & 941 & 7 & 100 \\
\hline MT32_29 & 0.08 & 0.21 & 0.07029 & 0.8 & 1.57387 & 1.4 & 0.16239 & 1.1 & 937 & 16 & 960 & 8 & 970 & 10 & 104 \\
\hline MT32_31 & 0.09 & 0.26 & 0.07011 & 0.8 & 1.56719 & 1.1 & 0.16213 & 0.8 & 932 & 16 & 957 & 7 & 969 & 8 & 104 \\
\hline MT32_38 & 0.06 & 0.17 & 0.07107 & 0.9 & 1.57600 & 1.3 & 0.16084 & 0.9 & 959 & 19 & 961 & 8 & 961 & 8 & 100 \\
\hline MT32_39 & 0.05 & 0.27 & 0.07137 & 0.6 & 1.58020 & 1.4 & 0.16058 & 1.3 & 968 & 12 & 962 & 9 & 960 & 11 & 99 \\
\hline MT32_38 & 0.00 & 0.16 & 0.07172 & 1.1 & 1.58902 & 1.4 & 0.16070 & 0.9 & 978 & 22 & 966 & 9 & 961 & 8 & 98 \\
\hline MT32_43 & 0.09 & 0.19 & 0.07026 & 0.8 & 1.57160 & 1.2 & 0.16223 & 0.9 & 936 & 16 & 959 & 8 & 969 & 8 & 104 \\
\hline MT32_46 & 0.21 & 0.22 & 0.07053 & 1.0 & 1.55485 & 1.7 & 0.15988 & 1.4 & 944 & 20 & 952 & 10 & 956 & 12 & 101 \\
\hline
\end{tabular}


migmatite (sample RF-128, model age of 2.75 and $\mathrm{e}_{\mathrm{Nd}}(2 \mathrm{Ga})$ of -9.59 ; sample RF-249, model age of $2.61 \mathrm{Ga}$ and $\mathrm{e}_{\mathrm{Nd}}(2 \mathrm{Ga})$ of -1.97$)$.

- Archean granites from PEAL represented by amphibole orthogneisses of the Entremontes Complex (sample RF-179, model age of $3.17 \mathrm{Ga}$ and $\mathrm{e}_{\mathrm{Nd}}(2.7 \mathrm{Ga})$ of -3.76$)$.
Granites within São Francisco Craton comprising pinkish alkali-rich migmatite near Riacho Seco, Curaça, Bahia State (sample RF-261, model age of 3.59 and $\mathrm{e}_{\mathrm{Nd}}$ $(2.7 \mathrm{Ga})$ of -6.70$)$, and mafic biotite gneiss with garnet and sillimanite found near Santa Maria da Boa Vista, Pernambuco State (sample RF-171, model age of 2.7 Ga and $\mathrm{e}_{\mathrm{Nd}}(2 \mathrm{Ga})$ of -1.61).

Table 10. Isotopic data from Sm-Nd of the study rocks.

\begin{tabular}{|c|c|c|c|c|c|c|c|}
\hline Sample & Sm(ppm) & $\mathrm{Nd}(\mathrm{ppm})$ & ${ }^{147} \mathrm{Sm} /{ }^{144} \mathrm{Nd}$ & ${ }^{143} \mathrm{Nd} /{ }^{144} \mathrm{Nd} \pm 2 \mathrm{SE}$ & $e_{N d}(0)$ & $e_{\mathrm{Nd}}(600 \mathrm{Ma})$ & (Ga) \\
\hline RF 022 & 4.429 & 23.747 & 0.1127 & $0.512091 \pm 13$ & -10.68 & -4.23 & 1.43 \\
\hline RF 027 & 10.143 & 60.474 & 0.1014 & $0.51212 \pm 32$ & -10.11 & -2.80 & 1.25 \\
\hline RF 068 & 0.619 & 2.731 & 0.1371 & $0.512092 \pm 9$ & -10.66 & -6.09 & 1.88 \\
\hline RF 322 & 15.443 & 74.099 & 0.1260 & $0.5121470 \pm 25$ & -9.58 & -4.16 & 1.54 \\
\hline \multirow[t]{2}{*}{ RF 415} & 4.551 & 25.801 & 0.1066 & $0.5117733 \pm 13$ & -16.87 & -9.97 & 1.79 \\
\hline & & & & & & $e_{\mathrm{Nd}}(1 \mathrm{Ga})$ & \\
\hline RF 003 & 6.466 & 36.024 & 0.1085 & $0.512092 \pm 17$ & -10.64 & 0.64 & 1.37 \\
\hline RF 010 & 10.845 & 50.698 & 0.1293 & $0.512228 \pm 13$ & -8.00 & 0.63 & 1.46 \\
\hline RF 033 & 12.198 & 62.360 & 0.1182 & $0.512057 \pm 13$ & -11.33 & -1.29 & 1.56 \\
\hline RF 270 & 5.278 & 27.755 & 0.1150 & $0.512039 \pm 11$ & -11.68 & -1.23 & 1.54 \\
\hline \multirow[t]{2}{*}{ RF 323} & 12.094 & 64.891 & 0.1127 & $0.5120705 \pm 15$ & -11.07 & -0.32 & 1.45 \\
\hline & & & & & & $\mathrm{e}_{\mathrm{Nd}}(2 \mathrm{Ga})$ & \\
\hline RF 040 & 11.781 & 75.738 & 0.0940 & $0.510939 \pm 13$ & -33.14 & -6.18 & 2.68 \\
\hline $\mathrm{RF} 111$ & 5.326 & 33.181 & 0.0970 & $0.510647 \pm 13$ & -38.83 & -13.30 & 3.14 \\
\hline RF 128 & 1.865 & 14.620 & 0.0771 & $0.510574 \pm 15$ & -40.27 & -9.59 & 2.75 \\
\hline RF 136 & 9.559 & 62.650 & 0.0922 & $0.510547 \pm 9$ & -40.79 & -14.02 & 3.14 \\
\hline RF 165 & 13.048 & 89.247 & 0.0884 & $0.510897 \pm 17$ & -33.97 & -6.18 & 2.6 \\
\hline RF 171 & 3.589 & 22.049 & 0.0984 & $0.511001 \pm 19$ & -31.94 & -6.72 & 2.7 \\
\hline RF 243 & 8.227 & 58.814 & 0.0846 & $0.510879 \pm 3$ & -34.31 & -5.55 & 2.55 \\
\hline RF 244 & 24.318 & 185.700 & 0.0792 & $0.510578 \pm 2$ & -40.18 & -10.06 & 2.79 \\
\hline RF 249 & 4.173 & 17.774 & 0.1419 & $0.511816 \pm 10$ & -16.03 & -1.97 & 2.61 \\
\hline \multirow[t]{2}{*}{ RF 267} & 23.038 & 202.566 & 0.0687 & $0.510671 \pm 3$ & -38.37 & -5.52 & 2.49 \\
\hline & & & & & & $\mathrm{e}_{\mathrm{Nd}}(2.7 \mathrm{Ga})$ & \\
\hline RF 179 & 14.362 & 83.267 & 0.1043 & $0.5107796 \pm 16$ & & -3.76 & 3.17 \\
\hline RF 261 & 24 & 103.108 & 0.1313 & $0.511132 \pm 9$ & -29.38 & -6.70 & 3.59 \\
\hline
\end{tabular}




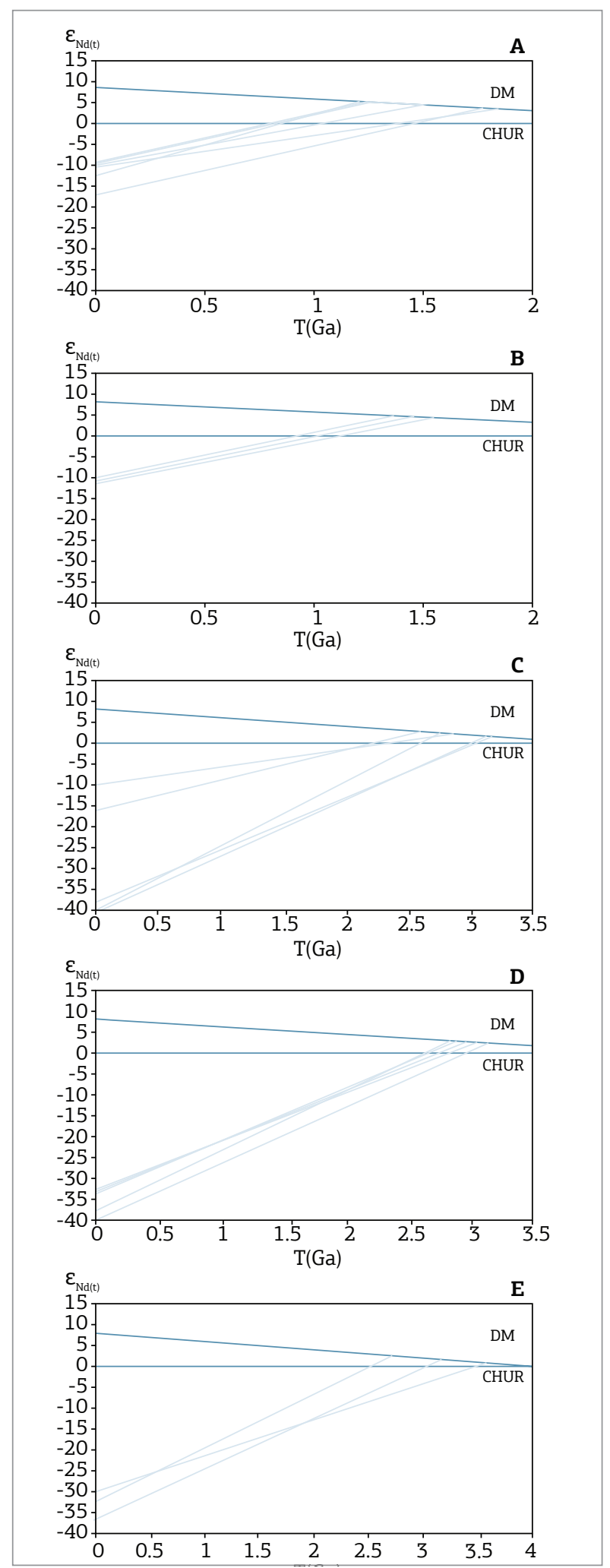

Figure 12. Diagram evolution of Nd to study rocks: (A) $\mathrm{e}_{\mathrm{Nd}}$ from Brazilian rocks from Pernambuco-Alagoas Domain (PEAL); (B) $e_{\mathrm{Nd}}$ Cariris Velhos rocks from PEAL; (C) $e_{\mathrm{Nd}}$ Paleoproterozoic rocks from PEAL; (D) $e_{\mathrm{Nd}}$ Paleoproterozoic rocks from Riacho Seco Nucleus; (E) $\mathrm{e}_{\mathrm{Nd}}$ São Francisco Craton rocks and Entremontes Complex.

\section{DISCUSSION}

The Entremontes Complex and metaplutonic bodies from RSN show Archean U-Pb and Sm-Nd ages, similar to rock units identified in the Congo and São Francisco Cratons (Bizzi et al. 2003; Teixeira et al. 2010), implying a correlation with the cratonic rocks.

Such Complex presents $\mathrm{U}-\mathrm{Pb}$ zircon age of $2,734 \pm 11 \mathrm{Ma}$ and $\mathrm{Sm}-\mathrm{Nd}$ model age of $3.16 \mathrm{Ga}$ and $\mathrm{e}_{\mathrm{Nd}}(\mathrm{T})$ of -3.8 . These data imply anatexis of, or contamination with, older continental crust in the granitoid protholith genesis. The Entremontes Complex may be considered an allochthonous strip or basement inlier within the Western PEAL (Cruz 2013). One possibility to be considered is that it would be a fragment of the Sáo Francisco Craton strongly deformed and displaced by the Brasiliano tectonics. An alternative hypothesis is that it may represent a microplate accreted to the Northern margin of São Francisco Craton during the Brasiliano orogeny.

The geochemical data reveal characteristics that are typically associated with intra-plate magmatism; however, others are common in subduction related granitoids. The Entremontes Complex, as indicated by the chemical data, is related to A-type magmatism most likely in a post-collisional setting during the end of Archean. Other units, in Borborema Province and São Francisco Craton, show similar ages and characteristics (Dantas et al. 2004; Teixeira 1997). The Entremontes Complex is the oldest rock unit in the PEAL.

The crystalline basement of the RSN represented by Riacho Seco Gneissic-migmatitic Complex presents a complex evolution, with Archean $(2,704 \pm 12 \mathrm{Ma})$ and Paleoproterozoic (1,992 \pm 27 and 2,461 \pm 24$)$ zircons, besides lower intercept ages $(548 \pm 76 \mathrm{Ma}$ and $559 \pm 40 \mathrm{Ma}$ ). Despite the array of zircon populations, the petrographic evidence clearly points to an igneous origin of these rocks. The Th-U ratios and images of zircon grains were not conclusive to separate the different zircon population ages in igneous or metamorphic. The age pattern suggests that igneous protoliths crystallized in the Paleoproterozoic are the result of reworking of Archean crust, with the unit also suffering the effects of the Brasiliano cycle. Other hypothesis would be the RSN rocks are Archean and metamorphosed with partial melting during the Paleoproterozoic. Two additional localities in the Riacho Seco gneissic-migmatitic Complex had samples analyzed (Brito Neves, personal communication). Additional data confirm the complexity of geological processes, which those rocks had gone through. 
Both samples presented three main age groups: 3.4 , 2.65, and 2.0 Ga; 3.2, 2.55, and 2.1 Ga. The RSN is located close to the boundary between the craton and PEAL, and it is difficult to establish which of the two tectonic domains it belongs to. Due the complexity showed by the data acquired, further studies are needed to better define this unit.

Most Paleoproterozoic rocks in Borborema Province have ages between 2.3 and $2.0 \mathrm{Ga}$ (Brito Neves et al. 2000; Neves 2003; Van Schmus et al. 2008). Fulgêncio Orthogneiss, however, has the age of $1.9 \mathrm{Ga}$, indicating a later stage in the Paleoproterozoic orogeny, a notion that is reinforced by their chemical characteristics associated with post-collisional setting. Few basement areas found in the Borborema Province have similar ages (Neves et al. 2014).

The U-Pb analyzes of zircon in Rocinha Orthogneiss indicate a concordia age of $956 \pm 2 \mathrm{Ma}$, slightly younger compared with the average age of Cariris Velhos granite known in literature $(990-960 \mathrm{Ma})$, including Lobo Orthogneiss (Brito \& Marinho 2012). The $\mathrm{Sm}-\mathrm{Nd}$ isotopic data yielded a model age value of 1.4 $\mathrm{Ga}$ and $\mathrm{e}_{\mathrm{Nd}}(\mathrm{T})$ of -0.8 , which represents contamination with, or anatexis of, older crustal material (Cruz \& Accioly 2013).

The large volume of Cariris Velhos granites (TonianStenian) is remarkable. Its counterparts in Africa are still unknown, however these rocks are abundant in the Alto Pajeú Domain of the Central Sub-province further to the North (Santos et al. 2010; Guimarães et al. 2012), and therefore Cariris Velhos Belt is extended to the Western PEAL. A variety of granitic intrusions attributed to the Cariris Velhos Event has chemical characteristics similar to volcanic arc granites as well as to A-type post-collisional granites (Cruz \& Accioly 2013; Santos et al. 2010; Kozuch 2003), suggesting that the Cariris Velhos event involved subduction process and does not represent purely an extensional episode.

Brasiliano plutons with Mesoproterozoic model ages are exposed in the Eastern PEAL, such as Águas Belas Pluton (Silva Filho et al. 2010). These bodies may be correlated with Brasiliano plutons in the Western part of the domain (Tab. 8).

The granitic-gneissic rocks in the Western PEAL with ages ranging from 1.0 to $0.6 \mathrm{Ga}$ (Brasiliano and Cariris Velhos plutons) show TDM periods between 1.2 and $1.8 \mathrm{Ga}$. These model ages are quite similar to those found in the Central African Fold Belt, in which TDM ages range from 1.0 to $1.8 \mathrm{Ga}$, mainly in the AdamawaYade Domain (Van Schmus et al. 2008).

\section{CONCLUSIONS}

Based on U-Pb and Sm-Nd isotopic data gathered in this study, it was possible to divide the granitoids of the study area (covering approximately $70 \%$ of the area of the Western Pernambuco-Alagoas Domain) into six main groups:

Brasiliano granites (Cryogenian-Ediacaran), with model ages ranging from Paleoproterozoic to Mesoproterozoic and chemical features similar to those of the high-K calc-alkaline series;

- Cariris Velhos granites (Tonian), presenting Mesoproterozoic model ages and chemical characteristics ranging from alkali-rich to calc-alkaline. This group includes Lobo $(974 \pm 8 \mathrm{Ma})$ and Rocinha (956 $\pm 2 \mathrm{Ma})$ orthogneisses;

Paleoproterozoic granites from PEAL, with model ages ranging between Neoarchean and Paleoproterozoic and high-K calc-alkaline chemical nature, including Fulgêncio Orthogneiss (1,996 $\pm 8 \mathrm{Ma})$;

Paleoproterozoic granites from RSN, with Archean model ages, mainly represented by Riacho Seco Gneissic-migmatitic Complex (1,992 $\pm 27 \mathrm{Ma})$;

- Archean granites from PEAL, represented by rocks of the Entremontes Complex with $\mathrm{U}-\mathrm{Pb}$ age of $2,734 \pm 11 \mathrm{Ma}$ and model age of $3.2 \mathrm{Ga}$;

São Francisco Craton granites with model ages ranging from Mesoarchean to Paleoproterozoic periods.

The Orosirian Fulgêncio Orthogneiss is exposed in an extensive area of the domain, and constitutes a very important exposure of older sialic basement rocks in the Western PEAL area. The basement of RSN (subdomain within PEAL) is formed mainly of Archean rocks reworked by Paleoproterozoic tectonic. Data acquired showed that the Western PEAL rocks were affected by four distinct tectonic events, starting with an Archean event, followed by a Paleoproterozoic, and subsequently affected by two others during the Neoproterozoic (Cariris Velhos and Brasiliano Cycle).

\section{ACKNOWLEDGMENTS}

The authors are grateful for the reviewers; for the isotope laboratory crew of University of Brasília; for Professor Benjamim Bley Brito Neves due to the geochronological information provided; for the Geologist Andrea Sander because of the great help on description of thin sections; and for the total support provided by the Geological Survey of Brazil (CPRM). 


\section{REFERENCES}

Almeida F.F.M. 1967. Origem e evolução da plataforma brasileira. Departamento Nacional de Produção Mineral, Mines and Geology Division, Boletim, 241, 36 p.

Almeida F.F.M., Hasui Y., Brito Neves B.B., Fuck R.A. 1977. Províncias estruturais brasileiras. In: 8 o Simpósio de Geologia do Nordeste, Campina Grande. Resumo das comunicações. Campina Grande: SBG, 79 p., Boletim Especial SBG, Núcleo Nordeste, 6, p. $12-13$.

Almeida F.F.M., Hasui Y., Brito Neves B.B., Fuck R.A. 1981. Brazilian structural provinces: an introduction. Earth Science Reviews, 17:1-29.

Angelim L.A.A., Kosin M. 2001. Aracaju NW: Folha SC.20-V Estados da Bahia, Pernambuco e Piauí Escala 1:500.000. Rio de Janeiro, CPRM, 1 CD-Rom, Programa Levantamentos Geológicos Básicos do Brasil.

Bittar S.M.B. 1998. Faixa Piancó-Alto Brígida: Terrenos tectonoestratigráficos sob regimes metamórficos e deformacionais contrastantes. Dissertação de Doutorado, Universidade de São Paulo, São Paulo, 126 p.

Bizzi L.A., Schobbenhaus C., Vidotti R.M., Gonçalves J.H. 2003. Geologia, tectônica e recursos minerais do Brasil: texto, mapas $\odot$ SIG. Brasília, Serviço Geológico do Brasil, 692 p.

Boynton W.V. 1984. Cosmochemistry of the rare earth elements: meteorite studies. In: Henderson P. (ed.) Rare Earth Element Geochemistry, Amsterdam Elsevier, p. 63-114.

Brito M.F.L.\&CruzR.F.2009. O Complexo Metavulcanossedimentar da região de Salgueiro/PE, Zona Transversal, Província Borborema, NE do Brasil. In: SBG, Simpósio de Geologia do Nordeste, 24, 2009. Fortaleza, Anais.., 201 p.

Brito M.F.L. \& Freitas S. 2011. Caracterização Petrológica e Geotectônica do Ortognaisse Lobo no Domínio PernambucoAlagoas, Província Borborema. In: $13^{\circ}$ Congresso Brasileiro de Geoquímica, Resumo expandido no Nordeste do Brasil, Gramado, Rio Grande do Sul.

Brito M.F.L. \& Marinho M.S. 2012. Carta Geológica da Folha Salgueiro SC.24-V-B-III. Estado de Pernambuco. Recife, CPRM, 2012. 1 mapa, colorido, 91,73 x 69,15 cm. Escala 1:100.000. Programa Geologia do Brasil, In: http://geobank.sa.cprm.gov.br.

Brito Neves B.B. 1983. O mapa geológico do Nordeste oriental do Brasil, escala 1/1.000.000. Tese de Livre-Docência, IG/USP, $177 \mathrm{p}$.

Brito Neves B.B., Santos E.J., Van Schmus W.R. 2000. Tectonic History of the Borborema Province, Northeast Brazil. In: Cordani U.G., Milani E.J., Thomaz Filho A., Campos D.A. (eds.) Tectonic Evolution of South America, Rio de Janeiro, 31st International Geological Congress, p. 151-182.

Brito Neves B.B., Sial A.N., Rand H.M., Manso V.V. 1982. The Pernambuco- Alagoas Massif, Northeastern Brazil. Revista Brasileira de Geociências, 12:240-250.

Brito Neves B.B., Van Schmus W.R., Santos E.J., Campos Neto M.C. 1995. O Evento Cariris Velhos na Província Borborema; integração de dados, implicações e perspectivas. Revista Brasileira de Geociências, 25(4):279-296.
Caby R., Sial A.N., Arthaud M.H., Vauchez A. 1991. Crustal evolution and the Brasiliano orogeny in northeast Brazil. In: Dallmeye R.D., Lécorché J.P. (eds.) The West African Orogens and Circum-Pacific-Atlantic Correlatives. Springer-Verlag, Berlin, p. 373-397.

Cruz R.F., Accioly A.C.A. 2013. Petrografia, geoquímica e idade $\mathrm{U} / \mathrm{Pb}$ do Ortognaisse Rocinha, no Domínio Pernambuco-Alagoas W da Província Borborema. Estudos Geológicos, 23(2):3-27.

Cruz R.F. 2013. Complexo entremontes, remanescente de embasamento arqueano no domínio Pernambuco-Alagoas $\mathrm{W}$ da província Borborema. In: XVI SNET - Simpósio Nacional de Estudos Tectônicos - Chapada dos Guimarães, Brasil, Expanded resume.

Dantas E.L., Van Schmus W.R., Hackspacher P.C., Brito Neves B.B. 1998. Archean accretion in the São José Campestre Massim, Borborema Province, NE of Brazil. Revista Brasileira de Geociências, 28:221-228

Dantas E.L., Van Schmus W.R., Hackspacher P.C., Fetter A., Brito Neves B.B., Cordani U.G., Nutman A.P., Williams I.S. 2004. The 3.4-3.5 Ga Sao José do Campestre massif, NE Brazil: remnants of the oldest crust in South America. Precambrian Research, 130:113-137.

De Paolo D.J. 1981. A neodymium and strontium isotopic study of the Mesozoic calc- alkaline granitic batholiths of the Sierra Nevada and Peninsular ranges. California Journal Geophysical Research, 86:10470; 10488.

Eby G.N. 1992. Chemical subdivision of the A-type granitoids: petrogenetic and tectonic implications. Geology, 20:641-644

Fetter A.H., Van Schmus W.R., Santos T.J.S., Nogueira Neto J.A., Arthaud M.H. 2000. U-Pb and Sm-Nd geochronological constraints on the crustal evolution of basement architecture of Ceará state, NW Borborema province, NE Brazil: implications for the existence of the Paleoproterozoic supercontinent 'Atlantica'. Revista Brasileira de Geociências, 30:102-106.

Frost B.R., Barnes C.G., Collins W.J., Arculus R.J., Ellis D.J., Frost C.D. 2001. A geochemical classification for granitic rocks. Journal of Petrology, 42:2033-2048

Ganade de Araujo C.E., Cordani U.G., Weinberg R.F., Basei M.A., Armstrong R., Sato K. 2014. Tracing Neoproterozoic subduction in the Borborema Province (NE-Brazil): Clues from U-Pb geochronology and Sr-Nd-Hf-O isotopes on granitoids and migmatites. Lithos, vol. 202-203, 2014, p. 167-189

Gioia S.M.C.L., Pimentel M.M. 2000. The Sm-Nd isotopic method in the Geochronology Laboratory of the University of Brasília. Anais da Academia Brasileira de Ciências, 72:219-245.

Guimarães I.P., Silva Filho A.F. 1998. Sm-Nd and Sr isotopic and $\mathrm{U}-\mathrm{Pb}$ geochronologic constraints for the evolution of the shoshonitic brasiliano Bom Jardim and Toritama Complexes: evidence for a Transamazonic enriched mantle under Borborema Tectonic Province, Brazil. International Geology Review, 40:500-527.

Guimarães I.P., Van Schmus W.R., Brito Neves B.B., Bittar S.M.B., Silva Filho A.F., Armstrong R. 2012. U-Pb zircon ages of orthogneisses and supracrustal rocks of the Cariris Velhos belt: Onset of Neoproterozoic rifting in the Borborema Province, NE Brazil. Precambrian Research, 192-195:52-77. 
Jardim De Sá E.F. 1994. A Faixa Seridó (Província Borborema, NE do Brasil) e o seu significado geodinâmico na Cadeia Brasiliana/ Pan-Africana. Tese de Doutorado, Instituto de Geociências, Universidade de Brasília, 803 p.

Kozuch M. 2003. Isotopic and Trace Element Geochemistry of Early Neoproterozoic Gneissic and Metavolcanic Rocks in the Cariris Velhos Orogen of the Borborema Province, Brazil, and Their Bearing on Tectonic Setting. PhD thesis, University of Kansas. 199 p.

Lerouge C., Cocherie A., Toteu S.F., Penaye J., Milesi J.P., Tchameni R. 2006. Shrimp U-Pb zircon age evidence for Paleoproterozoic sedimentation and $2.05 \mathrm{Ga}$ syntectonic plutonism in the Nyong Group, South Western Cameroon: consequences for the Eburnean-Transamazonian belt of NE Brazil and Central Africa'. Journal of African Earth Sciences, vol. 44, pp. 413-427.

Ludwig K.R. 2000. Decay constant errors in U-Pb concordiaintercept ages. Chemical Geology, 166:315-318.

Mascarenhas J.F., Garcia T.W. 1989. Mapa geocronológico do Estado da Bahia. Escala 1:1.000.000. Texto explicativo. Salvador, SME/Superintendência de Geologia e Recursos Minerais, 186 p.

Medeiros V.C. 2000. Aracaju NE: folha SC.24-X estados da Paraíba, Pernambuco, Alagoas, Sergipe e Bahia. Escala 1:500.000. Brasília, CPRM, 1 CD-ROM; mapas. Programa Levantamentos Geológicos Básicos do Brasil - PLGB.

Medeiros V.C. 2004. Evolução geodinâmica e condicionamento estrutural dos terrenos Piancó-Alto Brígida e Alto Pajeú. Domínio da Zona Transversal, NE do Brasil. Natal. Tese de Doutorado, PPGG, Universidade Federal do Rio Grande do Norte, $200 \mathrm{p}$

Medeiros V.C., Santos E.J. 1998. Folha Garanhuns (SC.24-X-B, escala 1:250.000). Integração Geológica (Relatório Interno), CPRM. Recife, Pernambuco, Brazil.

Neves S.P. 2003. Proterozoic history of the Borborema Province (NE Brazil): correlations with neighboring cratons and PanAfrican belts, and implications for the evolution of western Gondwana. Tectonics, 22:10-31.

Neves S.P., Lages G.A., Brasilino R.G., Miranda A.W.A. 2014. Paleoproterozoic accretionary and collisional processes and the built-up of the Borborema Province (NE Brazil): geochronological and geochemical evidence from the Central Domain. Journal of South American Earth Sciences, doi: 10.1016/j.jsames.2014.06.009

Neves S.P. Vauchez A., Feraud G. 2000. Tectono-thermal evolution, magma emplacement, and shear zone development in the Caruaru area (Borborema Province, NE Brazil). Precambrian Research, 99:1-32.

Neves S.P., Bruguier O., Vauchez A., Bosch D., Silva J.M.R., Mariano G. 2006. Timing of crust formation, deposition of supracrustal sequences, and Transamazonian and Brasiliano metamorphism in the East Pernambuco belt (Borborema Province, NE Brazil): Implications for western Gondwana assembly. Precambrian Research, 149:197-216.

Oliveira E.P., Toteu S.F., Araújo M.N.C., Carvalho M.J., Nascimento R.S., Bueno J.F., McNaughton N., Basilici G. 2006. Geologic correlation between the Neoproterozoic Sergipano belt (NE Brazil) and the Yaoundé belt (Cameroon, Africa). Journal of African Earth Sciences, 44:470-478.

Pearce J.A. 1996. Sources and settings of granitic rocks. Episodes, p. $120-125$
Pearce J.A. Harris N.W. Tindle A.G. 1984. Trace element discrimination diagrams for the tectonic interpretation of granitic rocks. Journal of Petrology, 25:956-983.

Santos E.J. 1995. O complexo granítico Lagoa das Pedras: acresção e colisão na região de Floresta (Pernambuco), Província Borborema. Tese de doutorado, Instituto de Geociências, Universidade de São Paulo, São Paulo, 219 p.

Santos E.J., Brito Neves B.B., Van Schmus W.R., Oliveira R.G., Medeiros V.C. 2000. An overall view on the displaced terrane arrangement of the Borborema Province, NE-Brazil. In: $31^{\text {st }}$ International Geological Congress, 2000, Rio de Janeiro. Proceedings, CD-ROM.

Santos E.J., Nutman A.P., Brito Neves B.B. 2004. Idades SHRIMP $\mathrm{U}-\mathrm{Pb}$ do Complexo Sertânia: implicações sobre a evolução tectônica da zona transversal, Província Borborema. Geologia USP, Série Científica 4:1-12

Santos E.J., Van Schmuss W.R., Kozuch M., Brito Neves B.B. 2010 The Cariris Velhos tectonic event in northeast Brazil. Journal of South American Earth Sciences, 29:61-76.

Shand S.J. 1943. Eruptive Rocks. Their Genesis, Composition, Classification, and Their Relation to Ore-Deposits with a Chapter on Meteorite. New York, John Wiley \& Sons.

Sial A.N. 1986. Granite-types in northeast Brazil: current knowledge. Revista Brasileira de Geociências, 16:54-72.

Silva L.C., Armstrong R., Noce C.M., Carneiro M.A., Pimentel M.M., Pedrosa-Soares A.C., Leite C.A., Vieira V.S., Silva M.A., Castro Paes V.J., Cardoso Filho J.M. 2002. Reavaliação da evolução geológica em terrenos Pré-cambrianos brasileiros com base em novos dados U-Pb Shrimp, Parte I: Províncias Borborema, Mantiqueira Meridional E Rio Negro-Juruena. Revista Brasileira de Geociências, 32(4):529-544

Silva Filho A.F., Guimarães I.P., Van Schmus W.R. 2002. Crustal evolution of the Pernambuco-Alagoas complex, Borborema province, NE Brazil: Nd isotopic data from Neoproterozoicgranitoids. Gondwana Research, 5:409-422

Silva Filho A., Guimarães I., Ferreira V.P., Armstrong R., Sial A.N. 2010. Ediacaran Águas Belas pluton, Northeastern Brazil: Evidence on age, emplacement and magma sources during Gondwana amalgamation. Gondwana Research, 17:676-687.

Shand S.J. (1943). Eruptive Rocks. Their Genesis, Composition, Classification, and Their Relation to Ore-Deposits with a Chapter on Meteorite. New York: John Wiley \& Sons.

Souza Z.S., Martin H., Peucat J.J., Sá E.F.J., Macedo M.H.F. 2007. Calc-alkaline magmatism at the Archean-Proterozoic transition the Caicó Complex Basement (NE Brazil). Journal of Petrology, 48:2149-2185.

Teixeira L.R. 1997. O Complexo Caraíba e a Suíte São José do Jacuípe no Cinturão Salvador-Curaçá (Bahia, Brasil): Petrologia, Geoquímica e Potencial Metalogenético. PhD thesis, Universidade Federal da Bahia, Salvador, 202 p.

Teixeira J.B.G., Silva M.G., Misi A., Cruz S.C.P. Sá J.H.S. 2010. Geotectonic setting and metallogeny of the northern São Francisco craton, Bahia, Brazil. Journal of South American Earth Sciences, 30(15):71-83.

Trompette R. 1994. Geology of Western Gondwana (2000-500 Ma). Balkema, Rotterdan, $350 \mathrm{p}$

Van Schmus W.R., Brito Neves B.B., Hackspacher P., Babinski M. 1995. $\mathrm{U} / \mathrm{Pb}$ and $\mathrm{Sm} / \mathrm{Nd}$ geochronolgic studies of eastern Borborema Province, Northeastern Brazil: initial conclusions. Journal of South American Earth Sciences, 8:267-288. 
Van Schmus W.R., Oliveira E.P., Silva Filho A.F., Toteu F., Penaye J., Guimarães I.P. 2008. Proterozoic Links between the Borborema Province, NE Brazil, and the Central African Fold Belt v. 294. Geological Society, London, Special Publication, p. 69-99.

Van Schmus W.R., Kozuch M., Brito Neves B.B. 2011. Precambrian history of the Zona Transversal of the Borborema Province, NE Brazil: Insights from Sm-Nd and U-Pb geochronology. Journal of South American Earth Sciences, 31:227-252.

Vauchez A., Neves S.P., Caby M., Corsini M., Egydio Silva M., Arthaud M.H., Amaro V. 1995. The Borborema shear zone system, NE Brazil. Journal of South American Earth Sciences, 8:247-266

Wood D.A., Joron J.L., Treuil M.A. 1979. Reappraisal of the use of trace elements to classify and discriminate between magma series erupted in different tectonic settings. Earth and Planetary Science Letters, 45:326-336.

Arquivo digital disponível on-line no site www.sbgeo.org.br 